\title{
ضرورة تحديث علم الكلام ومستوياتُه
}

$*$ ياسين السالمي

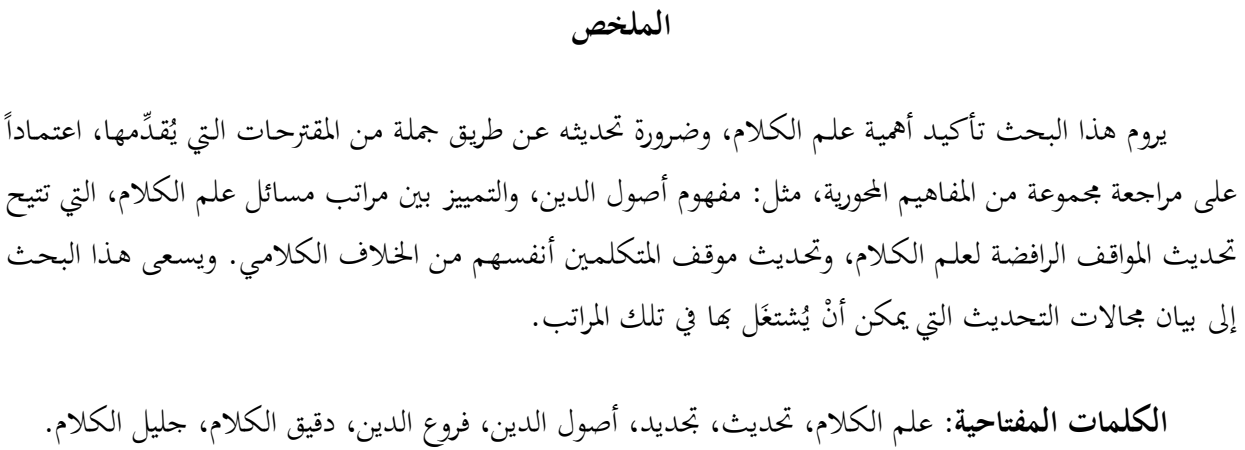

The need for the renewal of Islamic Theology and its levels

Yasin al-Salmi

\begin{abstract}
This study emphasizes the importance of Islamic Theology and the need for its renewal, and the update of its levels through a number of suggestions, based on the review of a set of central concepts, with specific focus of the concept of foundations of the religion. The study tries to distinguish between ranks of theology which allows updating positions on theology rejection, update positions of theologians themselves on theology dispute, and explain areas of these ranks that deserve the renewal.
\end{abstract}

Keywords: Islamic theology, Update and renewal, Foundations of the religion, Branches of the religion, Subtle questions of theology, Major questions of theology.

$$
\begin{aligned}
& \text { * أستاذ الفرق وعلم الكلام بمعهد محمد السادس للقراءات والدراسات القرآنية- جامعة القرويين، الرباط- المملكة } \\
& \text { المغربية، البريد الإلكتروني: gassineessalmi@gmail.com }
\end{aligned}
$$

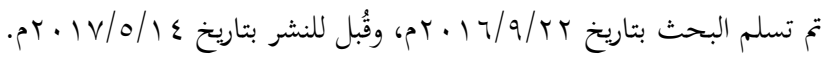




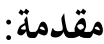

لا تخفى على الباحثين أهمية علم الكلام، سواء في القديع أو الحديث؛ إذ يُعَدُّ -إلى جانب علم أصول الفقه- انعكاساً لمنهج التفكير الإسلامي، وبتحلياً من بتحلياته العقلية.

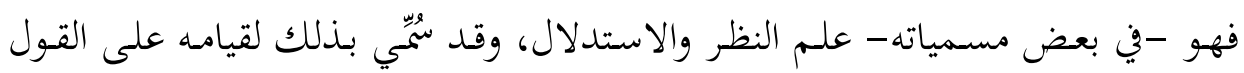

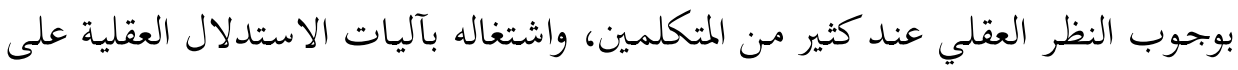
المسائل الإيمانية.

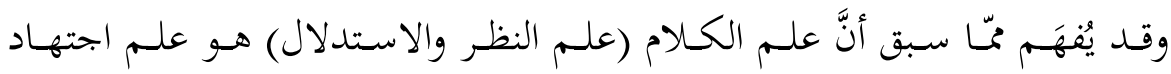

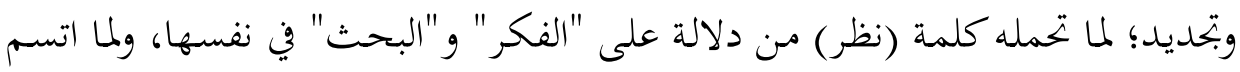

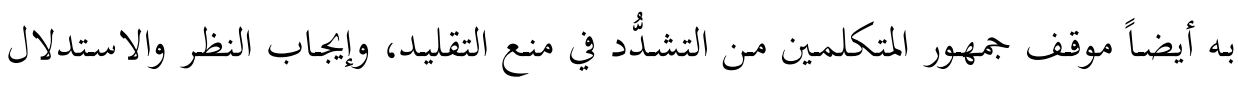

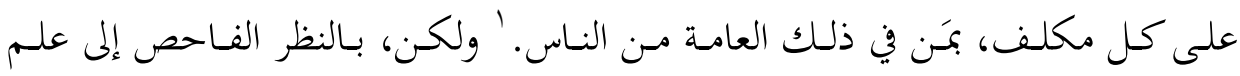

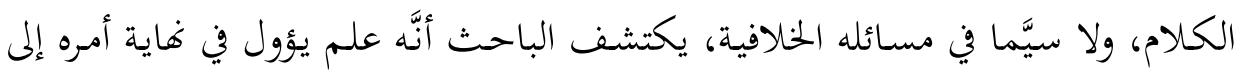

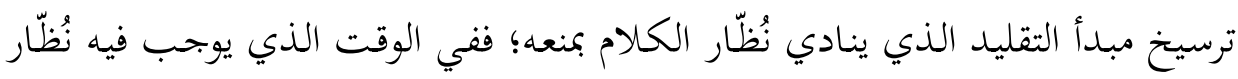

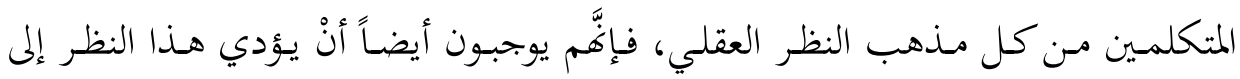

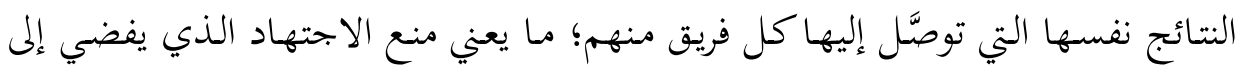

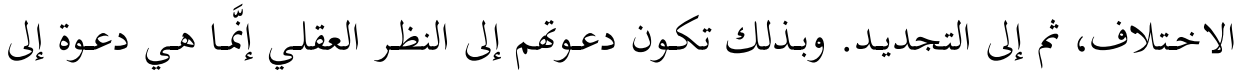

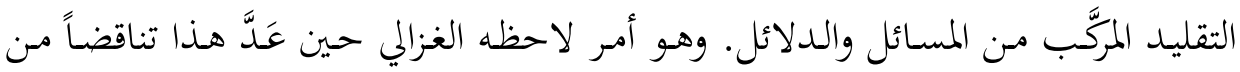

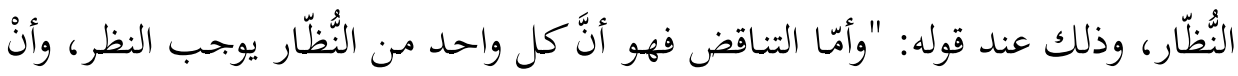

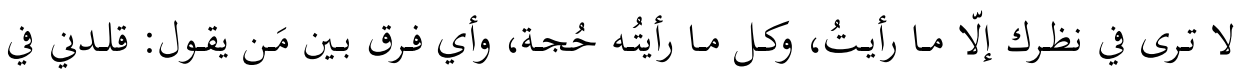

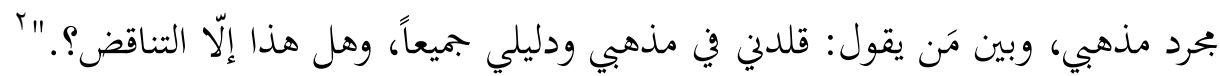
وأكثر ما يتجلى فيه هذا الجمود والتقليد المركَّب عند المتكلمـين هو الإقصاء المتبادل

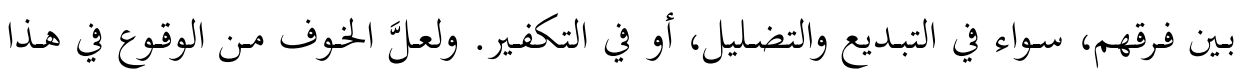

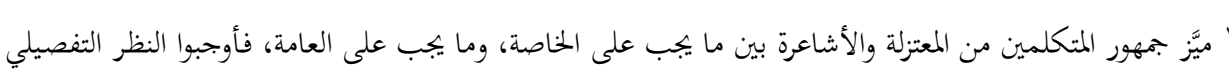

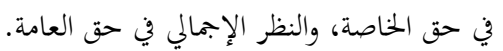

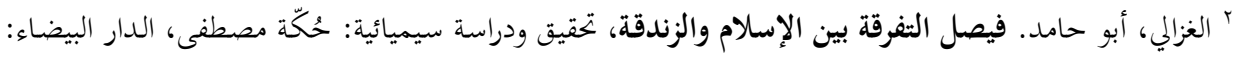

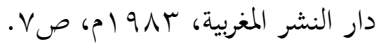


الإقصاء هو ما جعل أتباع كل فرقة لا يخرجون عن الأصول الكبرى التي أسَّسها أئمتهم،

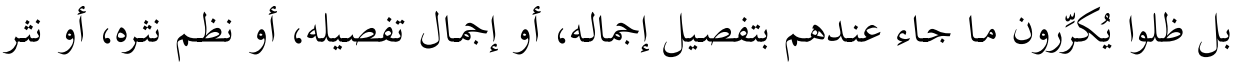
نظمه، فكثرت الحواشي والمختصرات، في حذر تام من التجديد في المسائل، بل الدلائل؛ تهرو خوفاً من الوقوع في البدعة والضلال، بل الكفر . وفي مقابل هؤلاء برزت طائفة من العلماء نادت بمنع الخوض في علم الكلام كراهةً

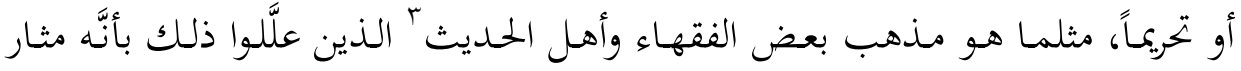
للشبهات والفتن، وطريق للابتداع.

ونظراً إلى الرفض الخارجي لعلم الكالام، والرفض الداخلي -بين المتكلمين أنفسهم-للاجتهاد المفضي إلى الاختلاف؛ ظلَّ هذا العلم، باستثناء محاولات محصورة معدودة، في

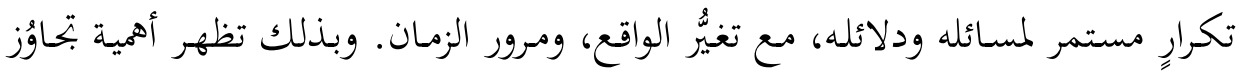

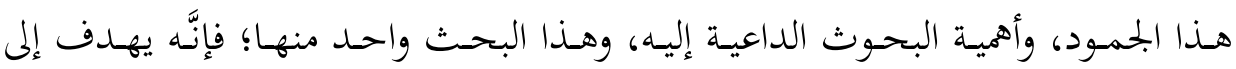

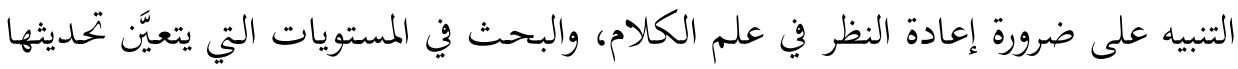

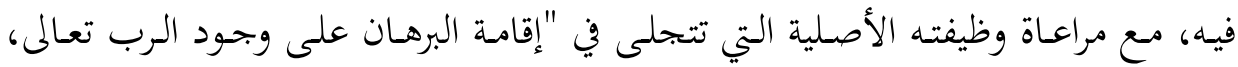

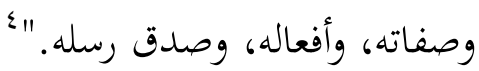

\section{أولاً: مفهوم التحديث وضرورته}

يعود أصل الجلذر (ح د ث) إلى وجـود الشيء بعـد العدم، وهو أصل واحـد مثلمـا

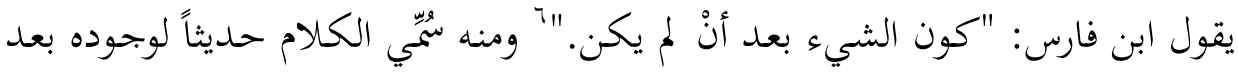

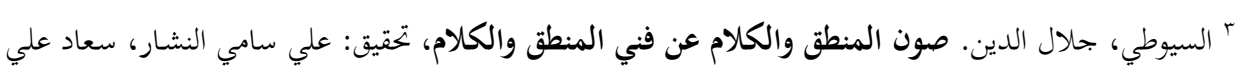

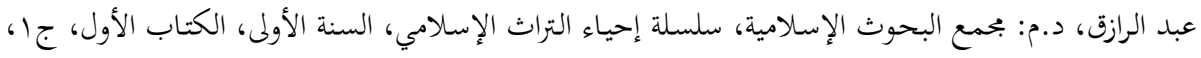
؛ الغزالي، أبو حامــ. الاقتصـاد في الاعتقاد، تحقيق: أنس محمد عدنان الشرفاوي، بيروت: دار المنهاج، طا،

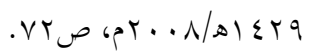
• نلاحظ تقارباً - إذا لم نقل ترادفاً- في المعنى بين لفظي "التحديث" و "التجديد". فبأيّههما عبَّنا لم نخرج عن المقصود العام.

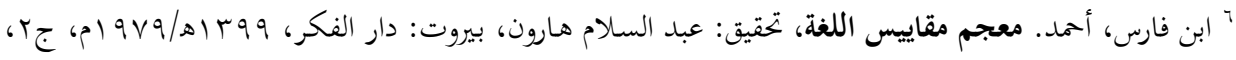




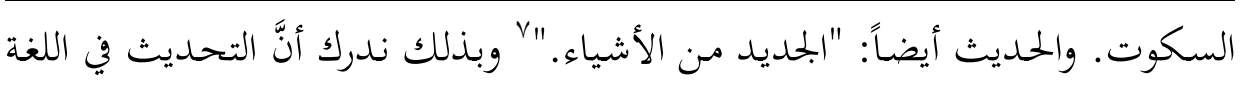

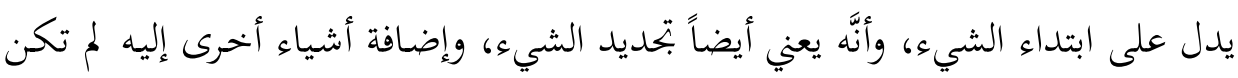
من قبلُ. وهو نفس ما نعنيه في هذا السياق بتحديث علم الكاءلام؛ إذ ليس معناه إلغاء

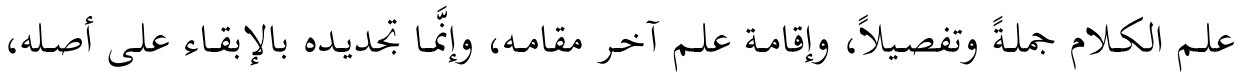

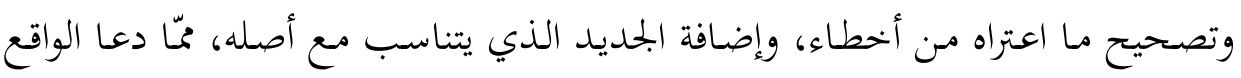

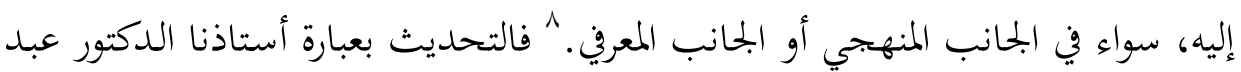

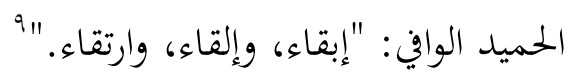

هذا ما يتعلق بمفهوم التحديث، أمّا ضرورته فتتجلى في أنَّ علم الكالام -شأنه في

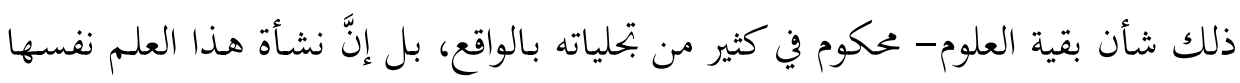

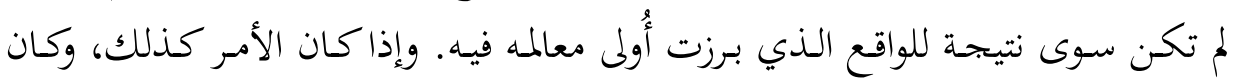

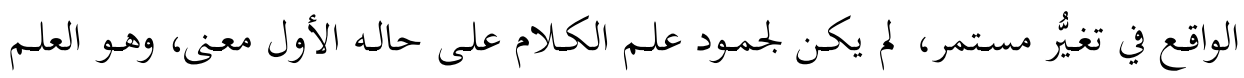
الذي يمنع التقليد، ويوجب النظر والاستدلال.

\section{ثانياً: المستوى الأول: تحديث المواقف من علم الكلام}

يُقصَد بهذا المستوى ضرورة تحديث النظر في المواقف من علم الكالام، ومن الخلاف

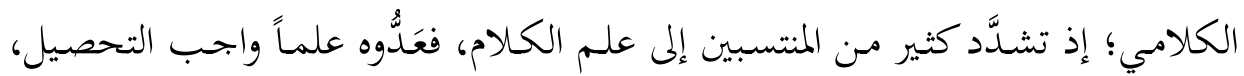

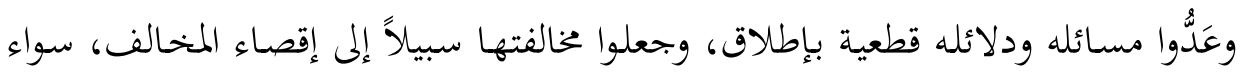

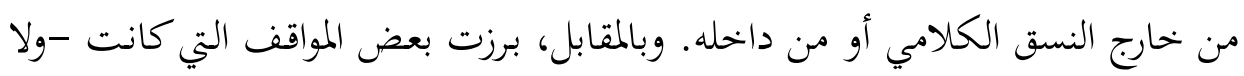

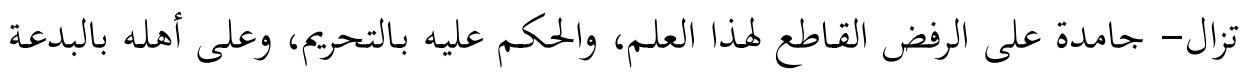

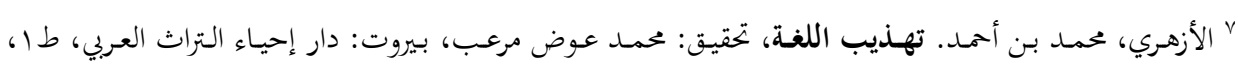

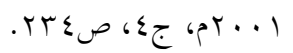

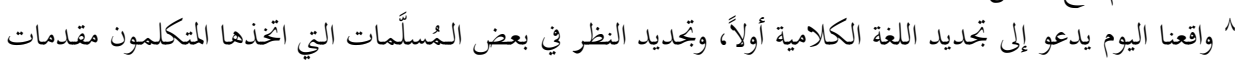

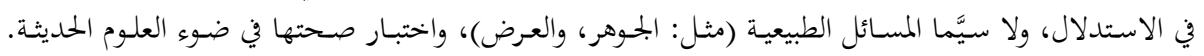

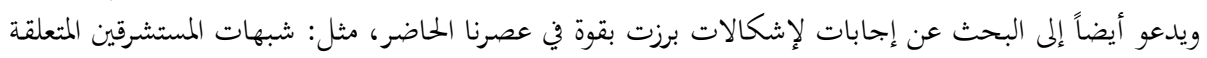

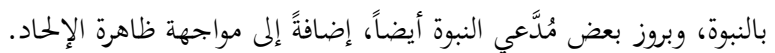

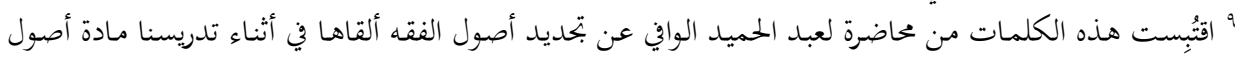

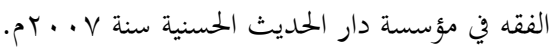


والضلال، بل بالكفر عند بعض الغلاة. وهي مواقف يُشهَد في جانبيها نوع من التطرف؛

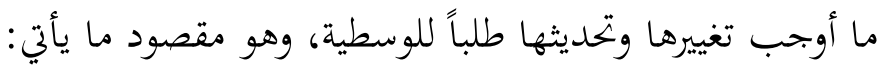

\section{I ـ الجمود والتقليد في علم الكالام: موجباته، وسبل التجاوز:}

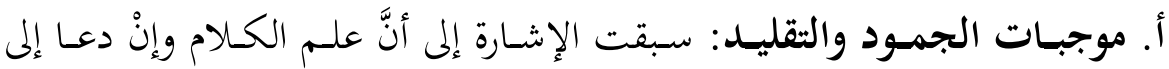

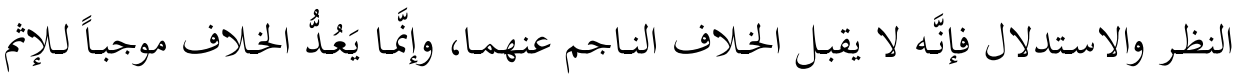

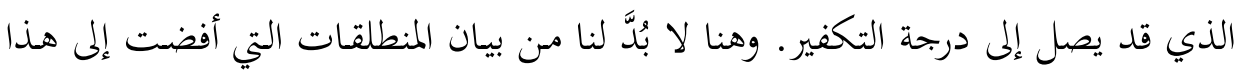

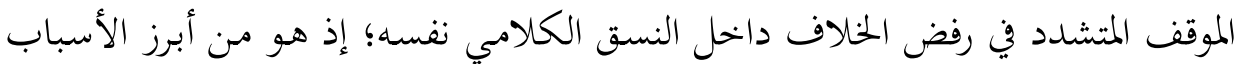

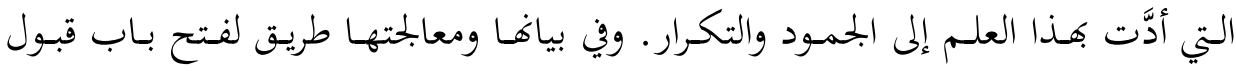

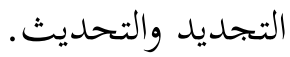

انطلق جمهـور المتكلمسين، وجمهـور الأصسوليين أيضـاً، مسن مُسـلَّمة مفادهـا أنَّ أصـول

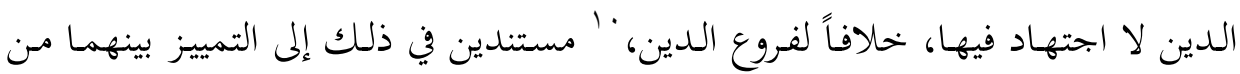

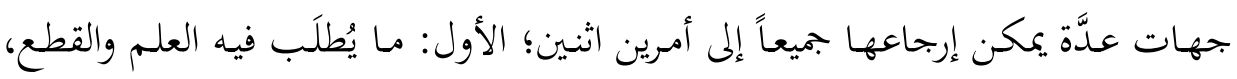
والثاني: ما يُطلَب فيه العمل والظن؛ فقد جعلوا أصول الدين [=العقديات والكاملاميات]

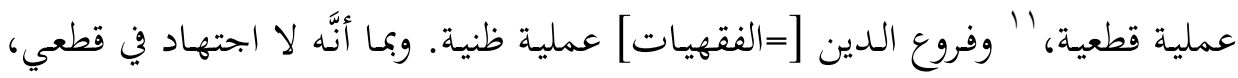
فلا اجتهاد في أصول الدين.

وهذا التأصيل مقبول نظرياً، بل يمكن أنْ يدعى فيه الإجماع، لكنَّ الإشكال الواقع

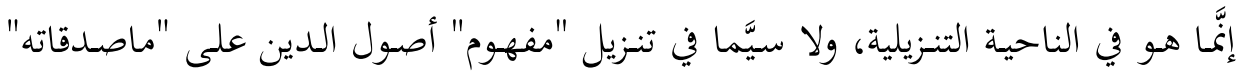

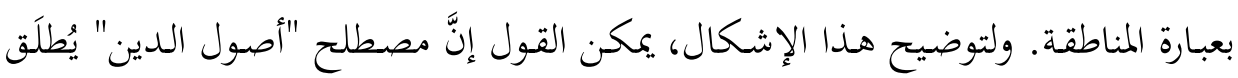

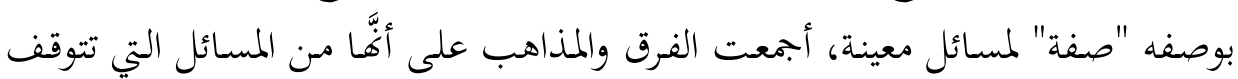

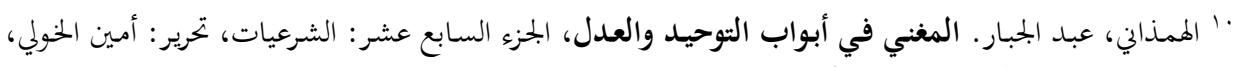

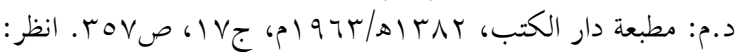

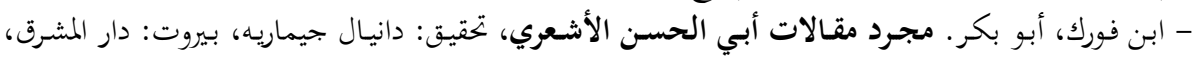

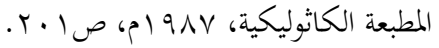

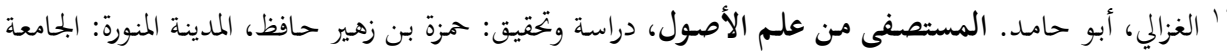

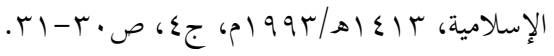


عليها صحة الدين، سواء من العقديات أو الفقهيات. ويُطلَق أيضاً بوصفه "اسماً" لعلم

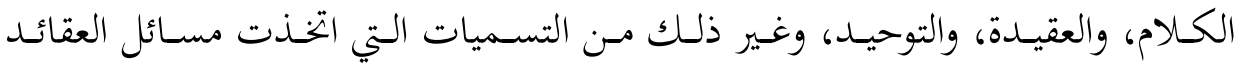
موضوعاً لدراستها.

وبهذا التمييز الأولي يمكن إيضاح الإشكال السابق بقول إنَّ مصطلح "أصول الدين"

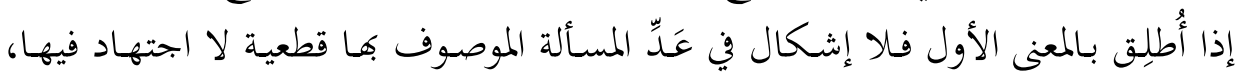

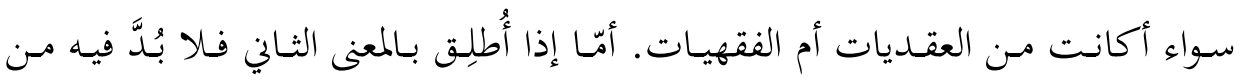

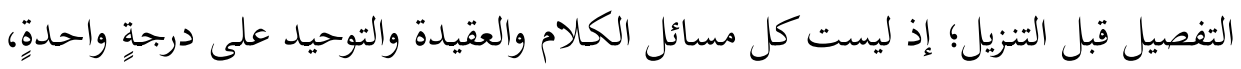

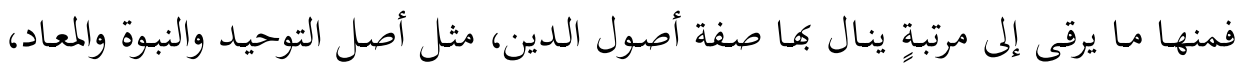

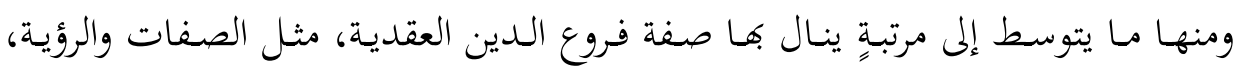

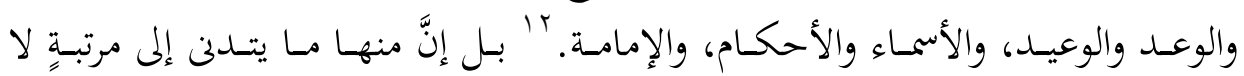

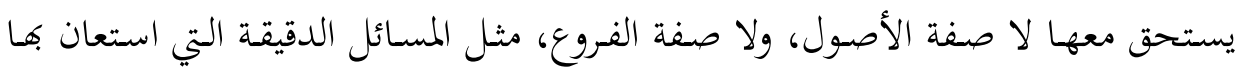

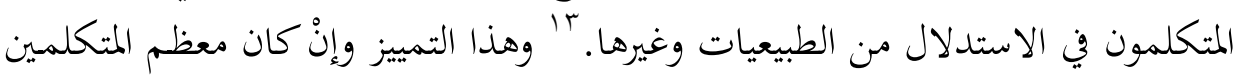

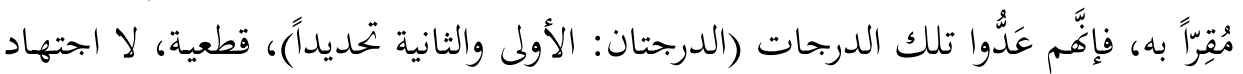

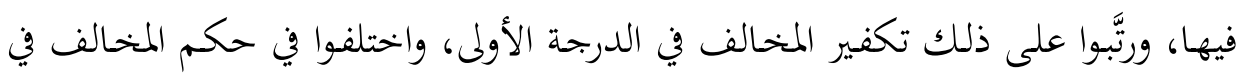

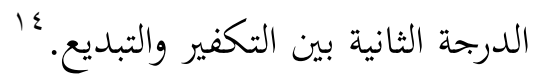

وبذلك يتضح لنا -بإجمال - أنَّ تلك المنطلقات كانت أهم أسباب الإقصاء المتبادل

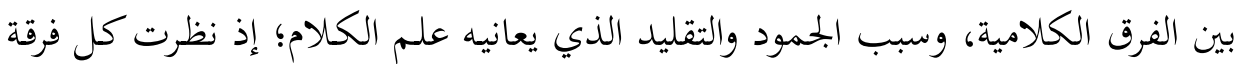
إلى أصول مذاهبها واختياراتها العقدية بوصفها أصول الدين القطعية، والقطعي لا اجتهاد فيه. ولذلك، كان لزاماً إعادة النظر في الخلاف الكافلامي ومراجعته، وإلزام الفرق الكاملامية بضرورة تحديث تلك المواقف، تأسيساً لتحديث العلم نفسه.

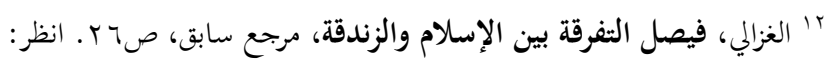

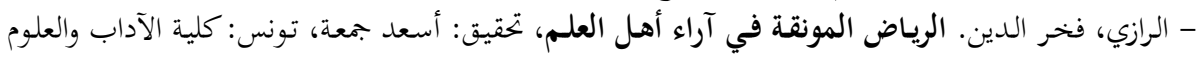

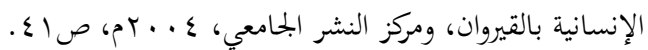

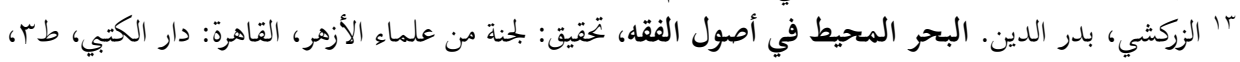

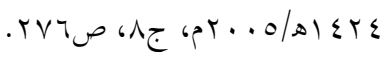

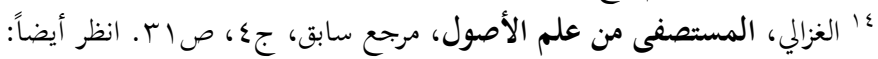

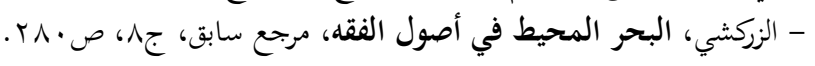


ب. سـبل تجـاؤز المنطلقـات السـابقة: يتعـيَّن علينـا، ونحـن نحاول مراجعـة الموقف

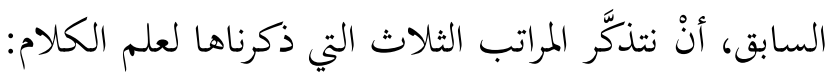
أمَّا المرتبـة الأولى فالإجمـاع حاصل على القـول بأهَّا عمليـة قطعيـة، وأنَّهَ لا اجتهاد

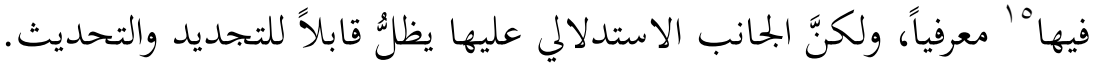
وأمَّـا المرتبـة الثانيـة فهي محل الخـلاف قـديماً وحسديثاً. وجمهـور المتكلمـين يجعلهـا مـن

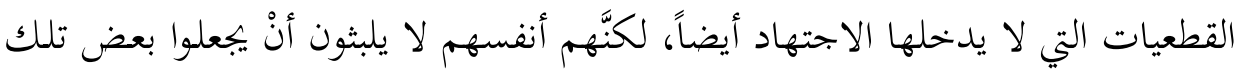

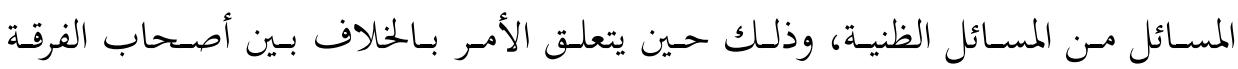

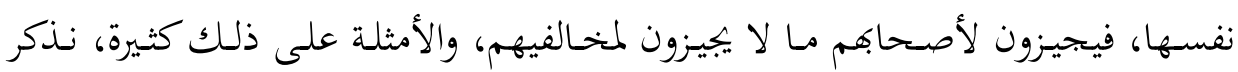

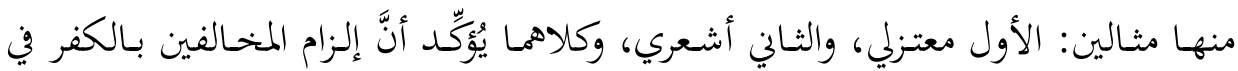
مسائل هذه المرتبة يفضي إلى تكفير الأصحاب أيضاً، والأمر ينعكس؛ ففي المثال الأول

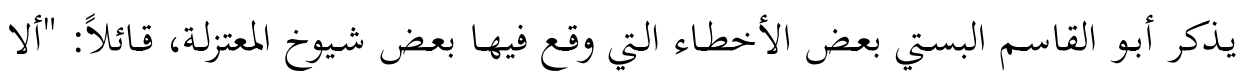

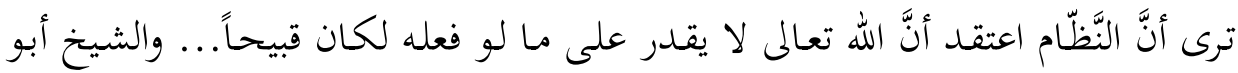

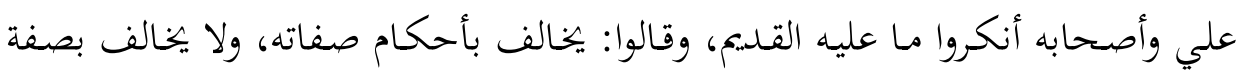

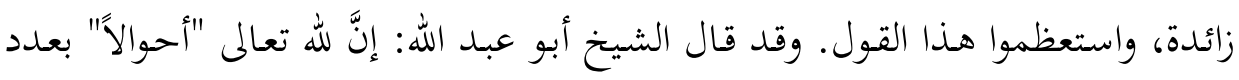

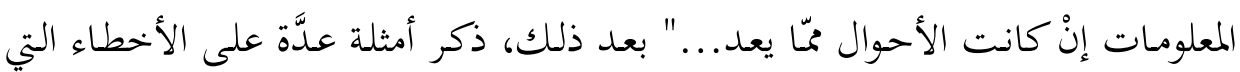

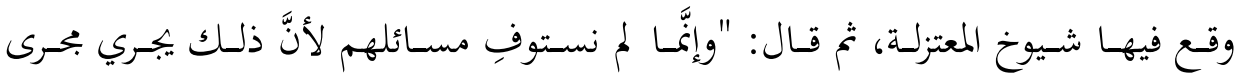

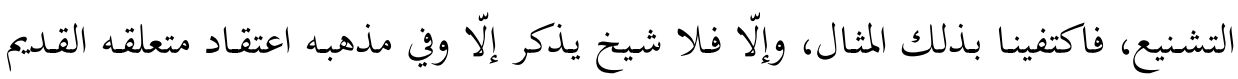
تعالى، وهو عندنا جهل، فيلزمنا تكفيرهم." "17

ولأنَّه لا يكفرهم، ولا يريد أنْ يقع في الخلل المنهجي الذي يؤدي به إلى التفريق بين

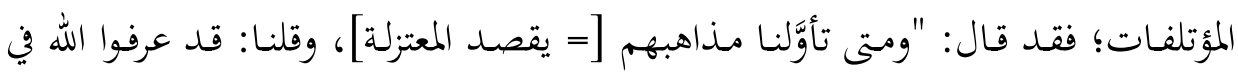

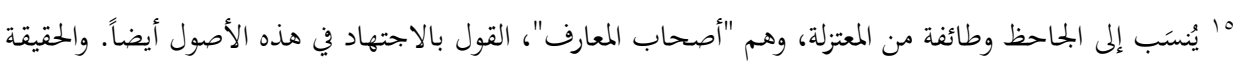

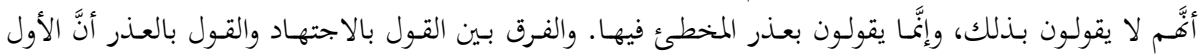

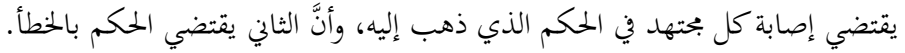

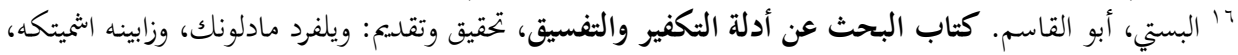

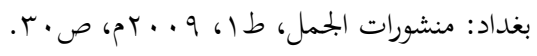


الجملة، وغلطهم في غير القديم، أو صرفنا خلافهم إلى عبارة أمكن ذكر مثل ما يعتذر به اله عنهم في كثير من المخالفين.

أمّا في المثـال الثـاني فيـذكر الرازي نصـاً طـويلاً يُعـدِّد فيـه اختلافـات الأشـاعرة في

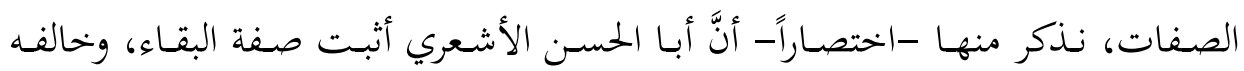

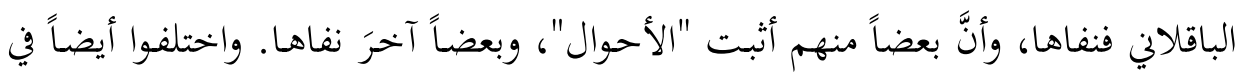

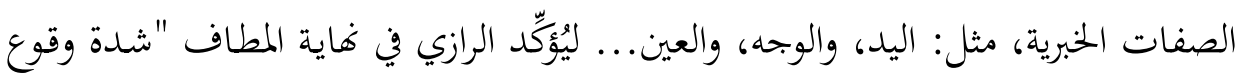

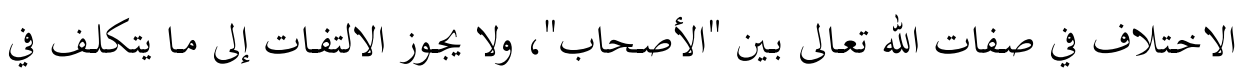

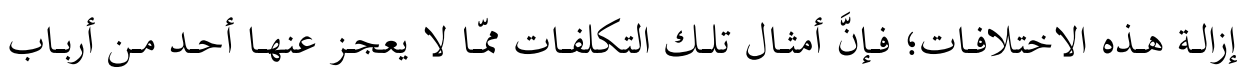
المذاهب. فنبت أنّا لو حكمنا بأنَّ الجها بشل بشيء من صفات اللهات الله تعالى يكون كفراً، يلزمنا

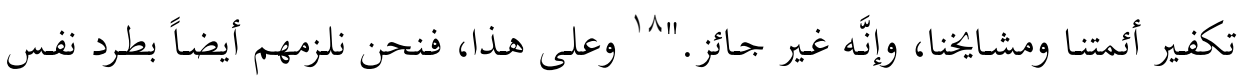

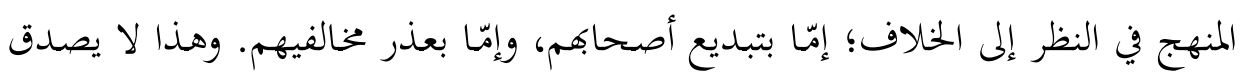
على علم الكلام فحسب، بل على كل علم خلافي. وفي هذا السياق، يتعيَّن علينا ملاحظة أمرين اثنين: الأول: أنَّ مسائل علم الكالام ليست كلها واجبة الاعتقاد، وإنَّما يجب منها اعتقاد الأصول الكبرى؛ أي التوحيد، والنبوة ولوازمها (الكتب، والملائكة، والمعاد)، وهي مسائل

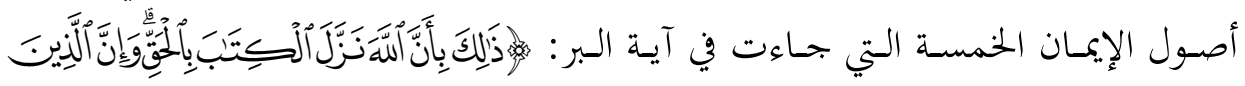

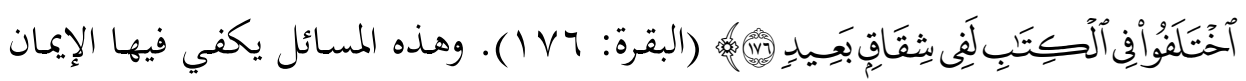

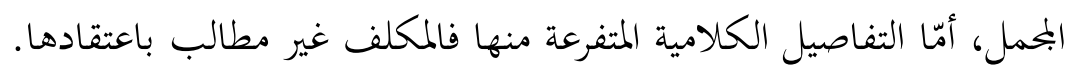
الثاني: أنَّ المسائل الخلافيـة المتفرعة مـن الأصول الكبرى لا ترقى إلى مرتبة القطعية،

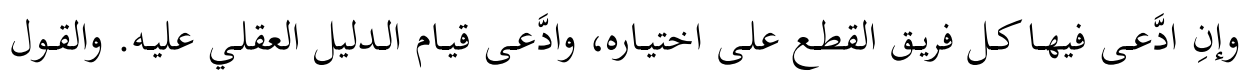

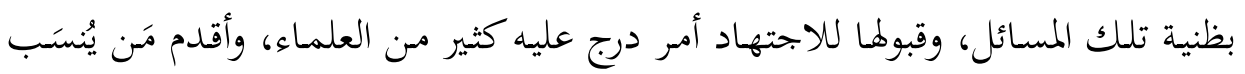

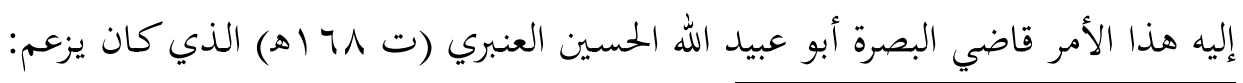

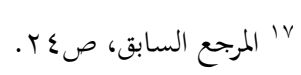

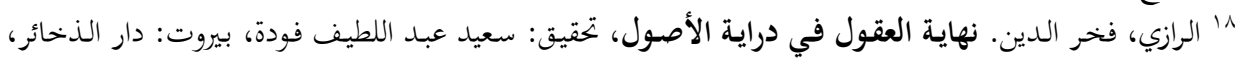




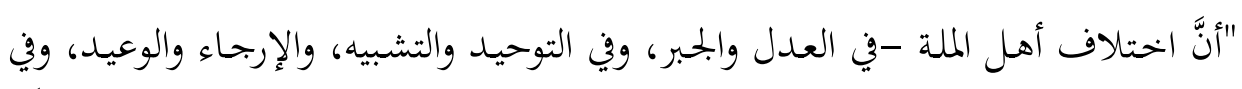

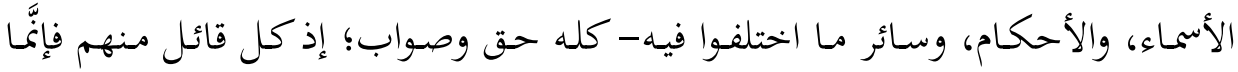

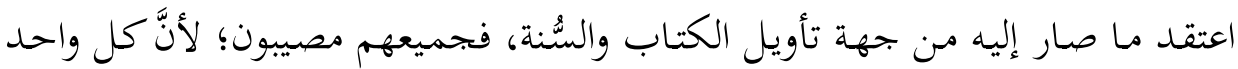

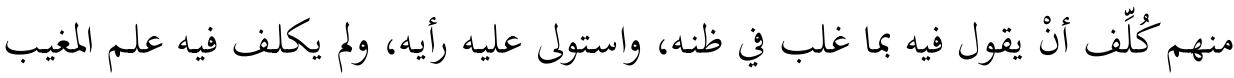

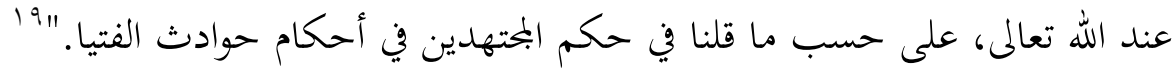
ولم يقصد العنبري بقوله (فجم-يعهم مصيبون) أنَّ مـا وصلوا إليه مـن الاعتقـادات

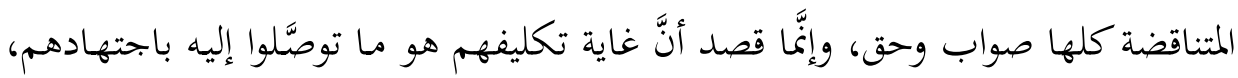

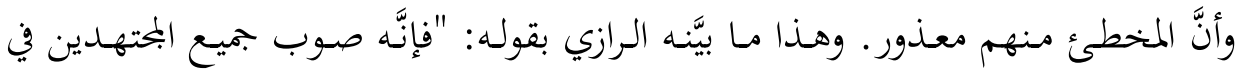

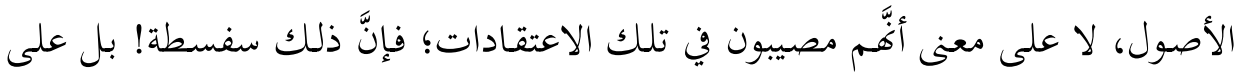

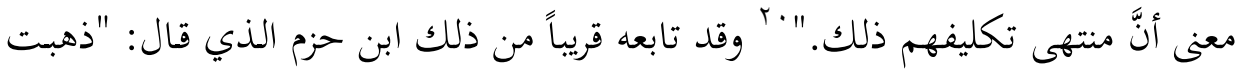

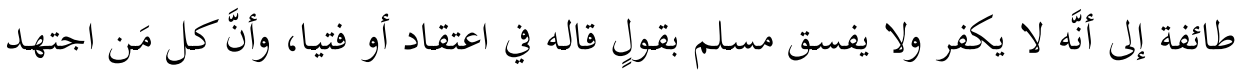

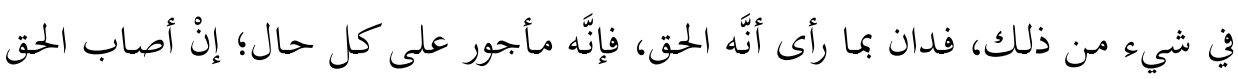

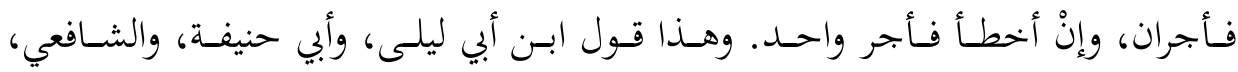

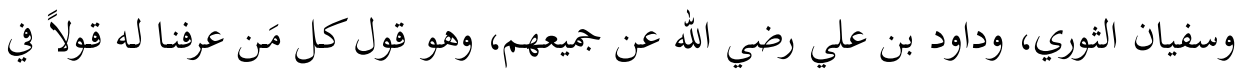

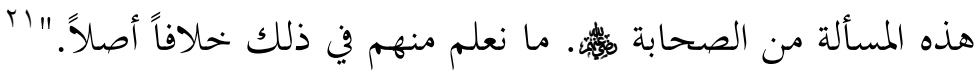

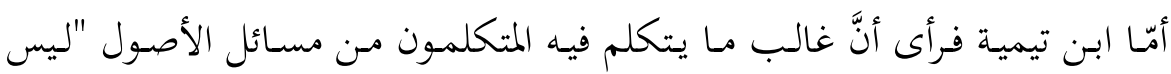

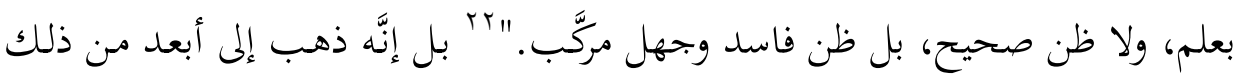

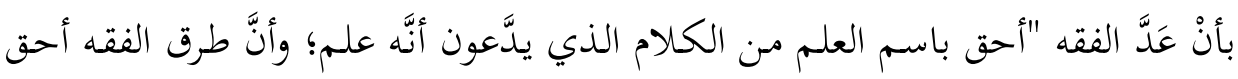

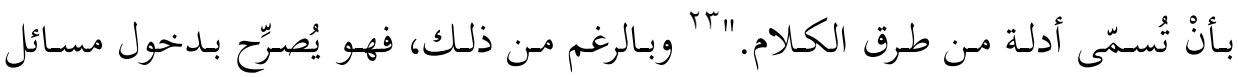

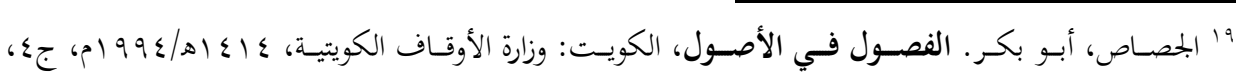
صQrvo

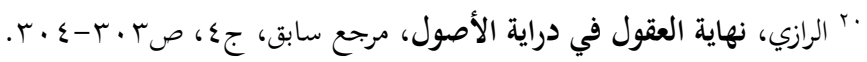

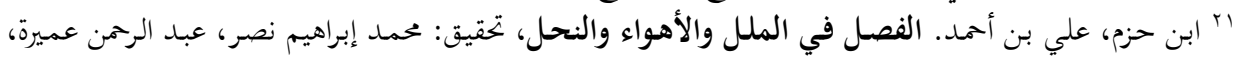

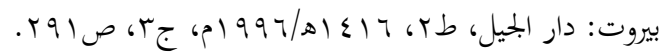

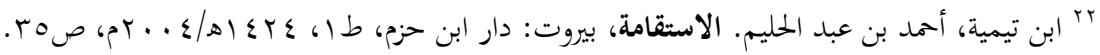

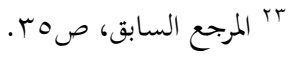


العقيدة تحت باب الاجتهاد، قائلاً: "الخطأ المغفور في الاجتهاد، هو في نوعي المسائل

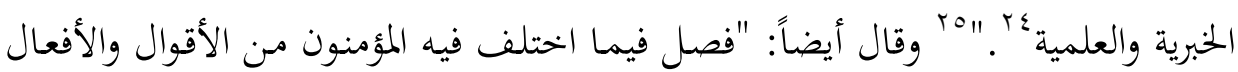

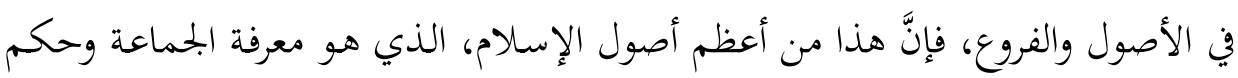

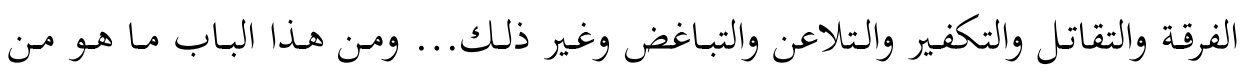

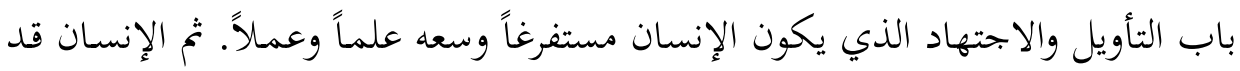

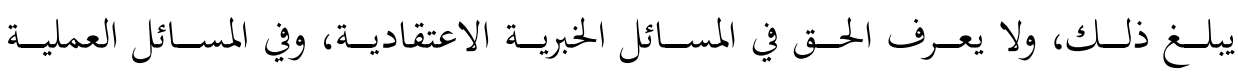

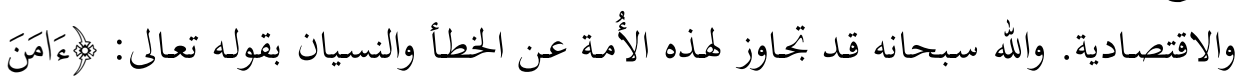

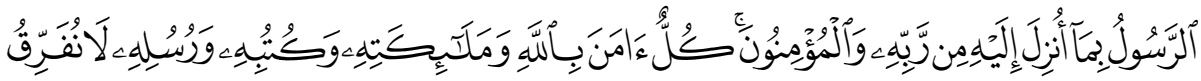

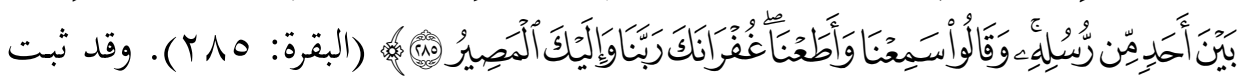

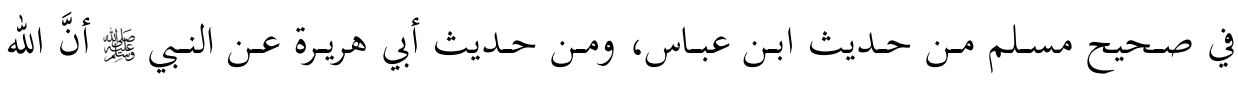

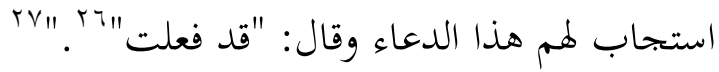

وليس المقصود في هذه الوريقات بيان أي المذاهب أصوب، وإنَّا بيان أنَّ مـا ادَّعى

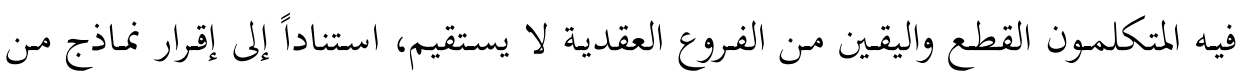

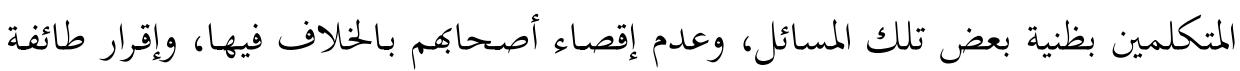
أخرى من خارج النسق الكلامي بظنيتها أيضاً.

\section{Y . جمود الموقف المعارض لعلم الكلام، وضرورة تحديثه:}

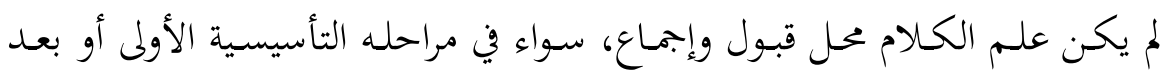

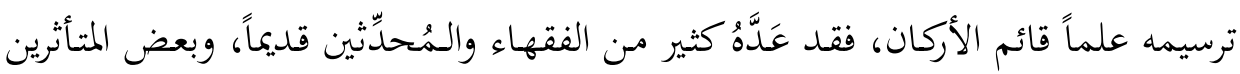

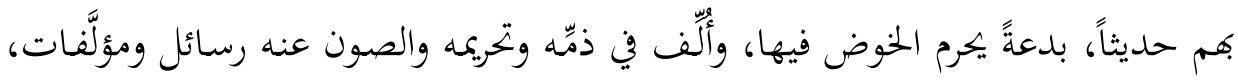

كُ كذا، والصواب: العملية.

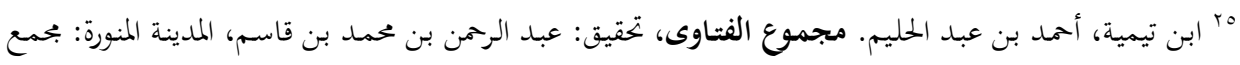

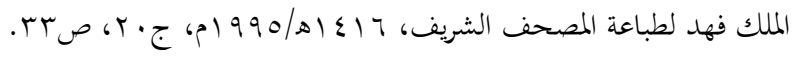

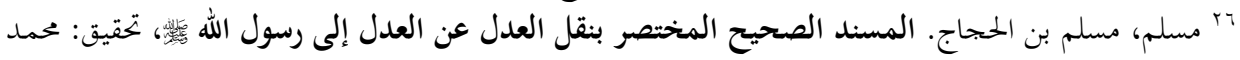

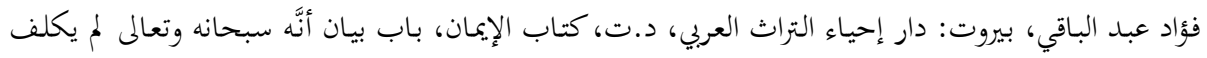




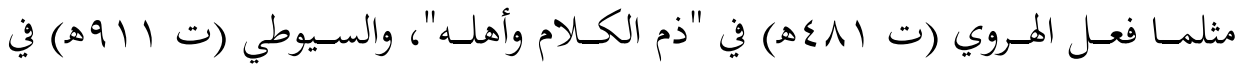

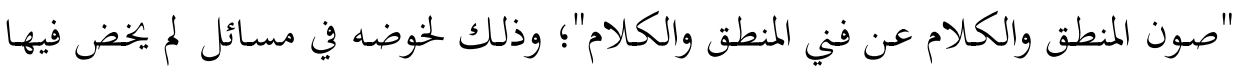

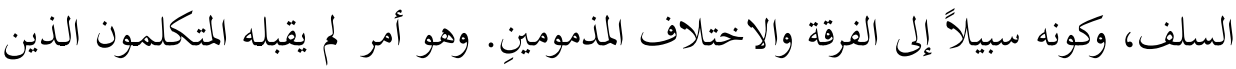

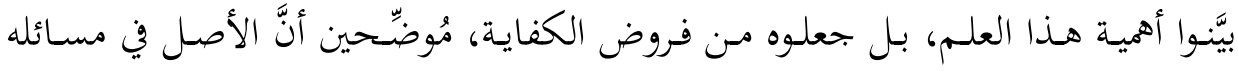

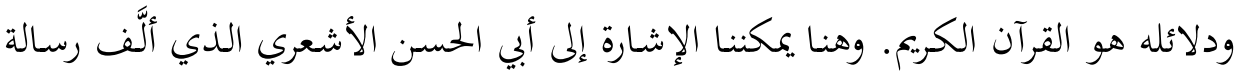

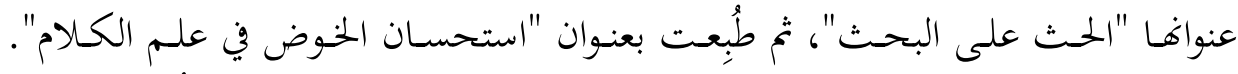

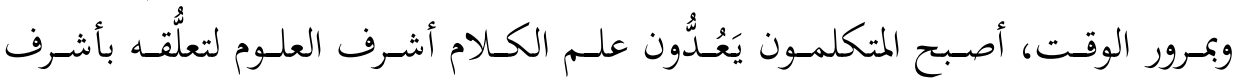

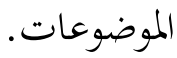

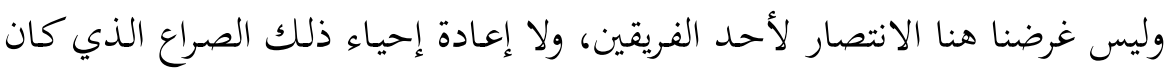

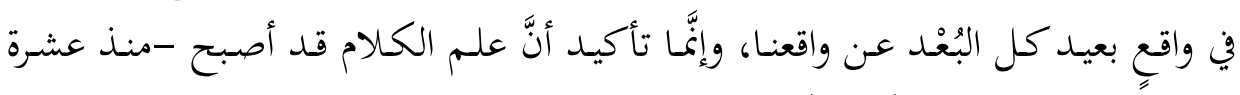

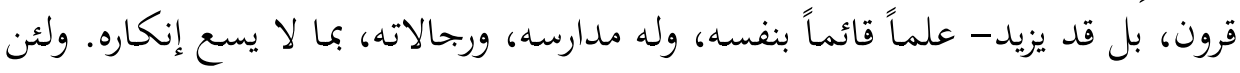

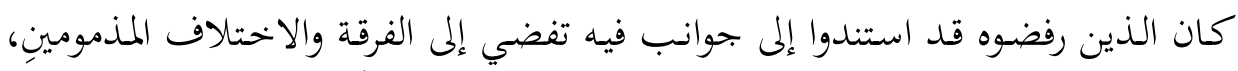

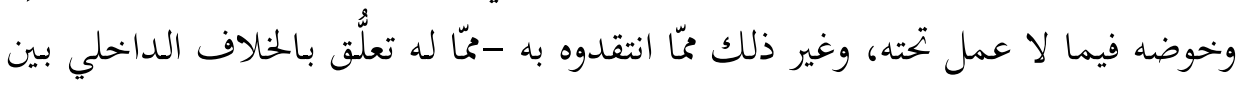

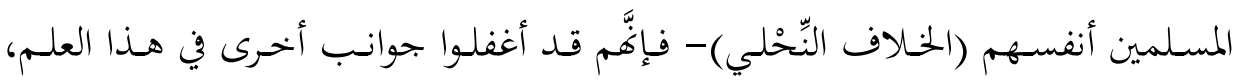

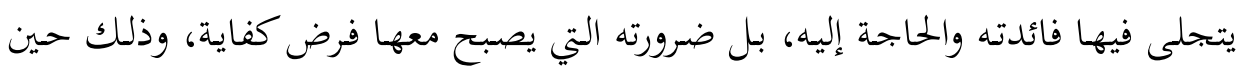

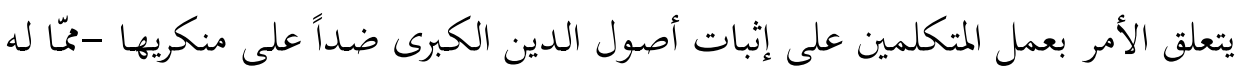

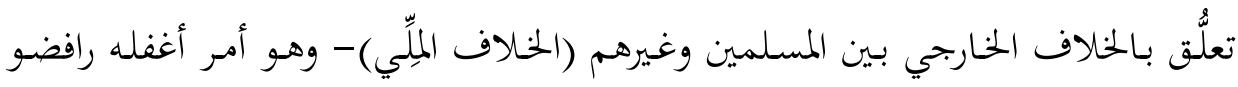

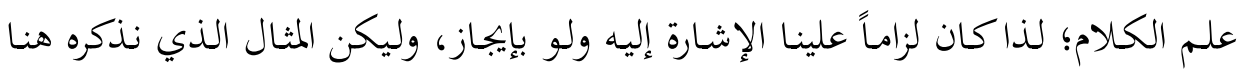

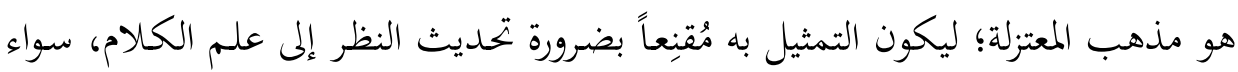

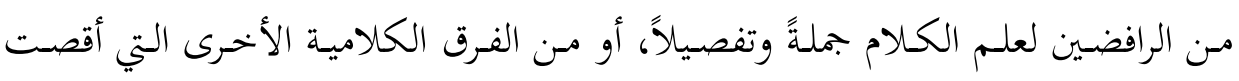

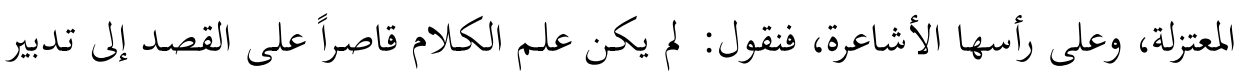

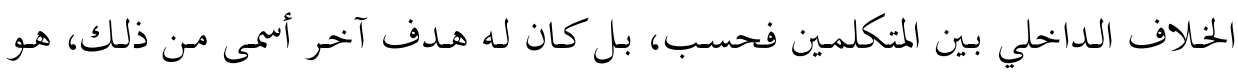

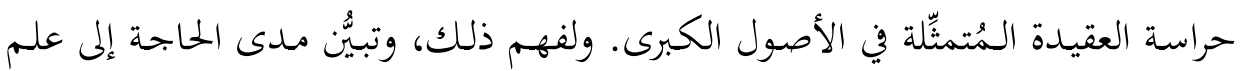

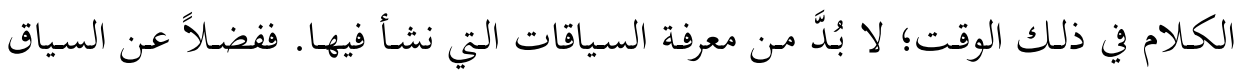

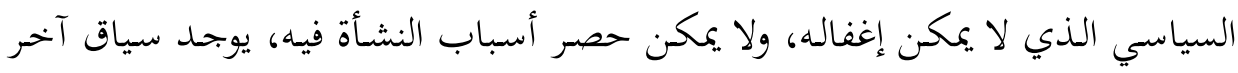




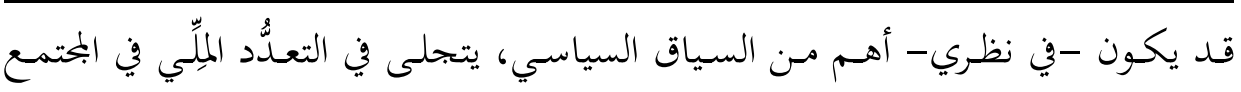
الإسلامي، المُتمثّل في العيش المشترك لبعض الأديان في البلاد الإسلامية، ولا سيَّما في

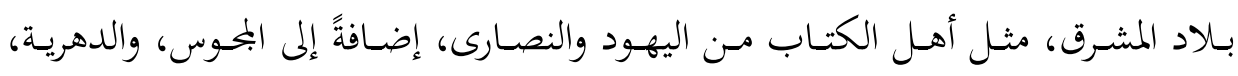

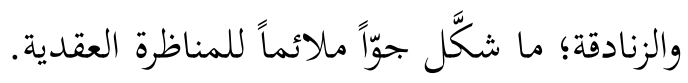

يقول الحميدي (ت ميـ هـ): "... سمعت أبا محمد عبد الله بن أبي زيد يسأل أبا عمر أحمد بن محمد بن سعدي المالكي عند وصوله إلى القيروان من ديار المشرق، وكان

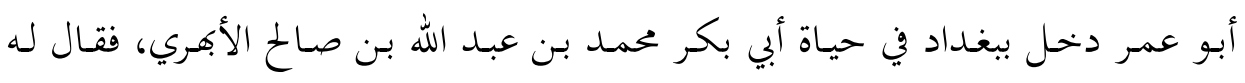

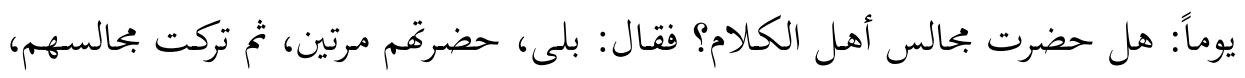

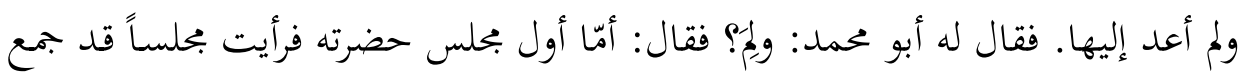

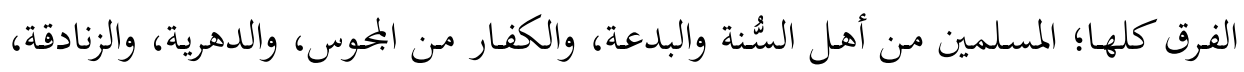
واليهود، والنصارى، وسائر أجناس الكفر . ولكل فرقة رئيس يتكلم على مذهبه، ويجادل

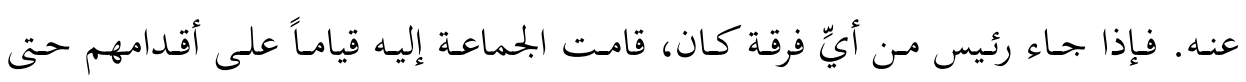

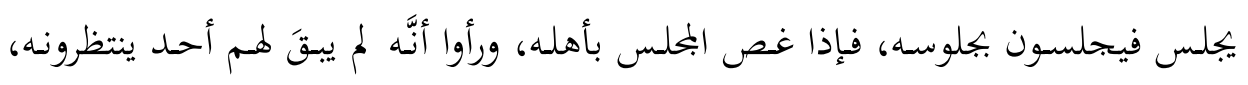

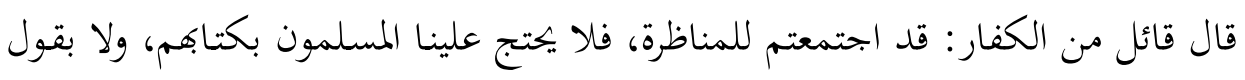

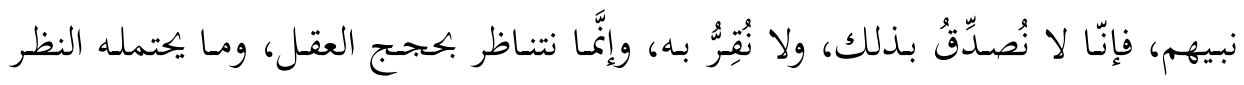

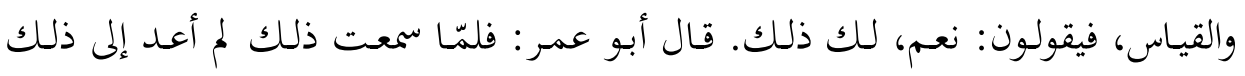

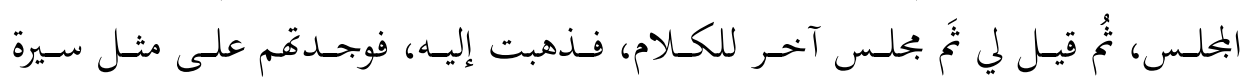

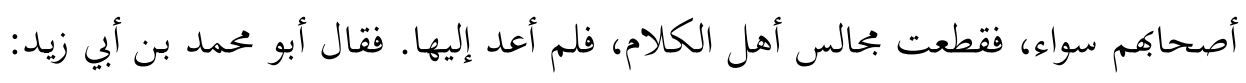

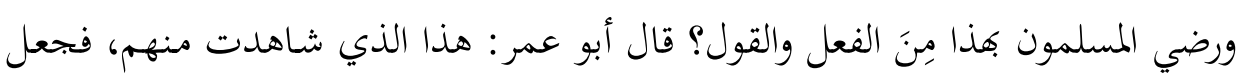

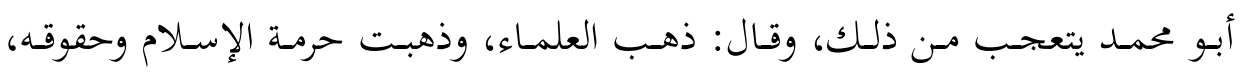

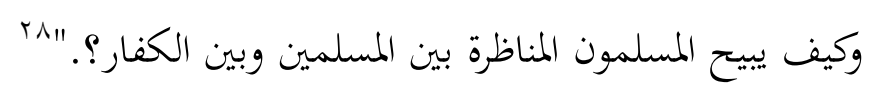

تشـير هـذه القصـة إلى مفارقة بـين موقف الفقهاء الـذي يُمثِّهـ ابـن أبي زيـد القـيرواني

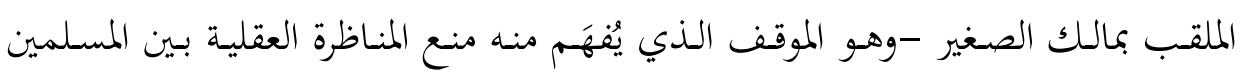
^^ الحميدي، محمد بن فتوح. جـذوة المقتبس في ذكر ولاة الأندلس، القاهرة: الدار المصرية للتأليف والنشر، 
والكفار - وموقف المتكلمين الذين خاضوا في هذه المناظرة؛ فقد كانت تُعََد في بغداد -

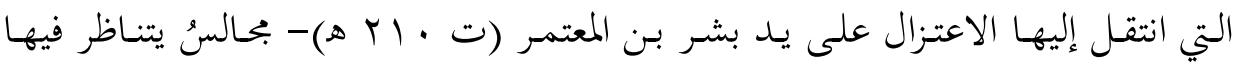

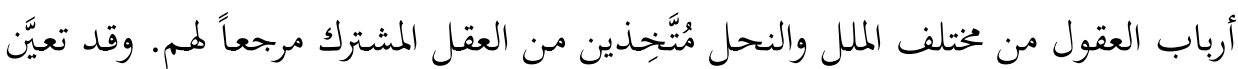

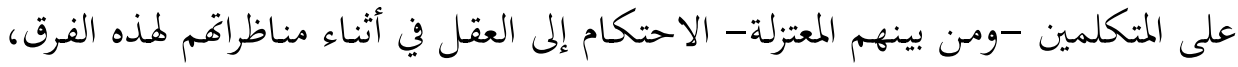

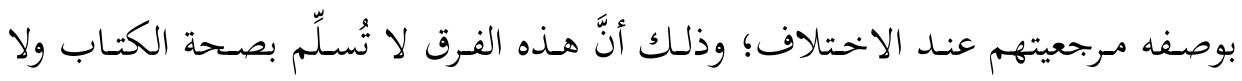

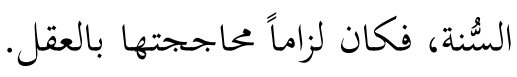

فالظاهر إذن أنَّ المتكلمـين قد اشتغلوا بمناظرة المخحالفين من أهل الملل، ولا شـكَّ في

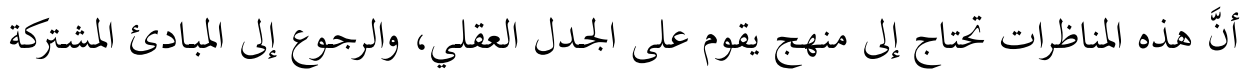

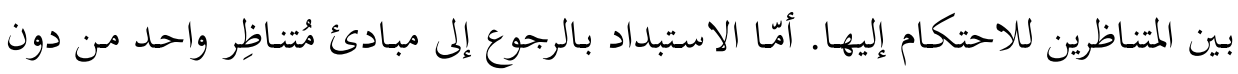

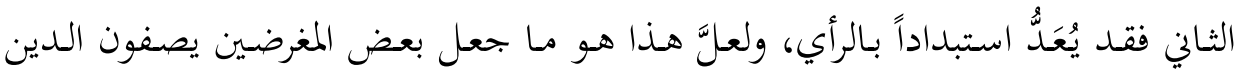

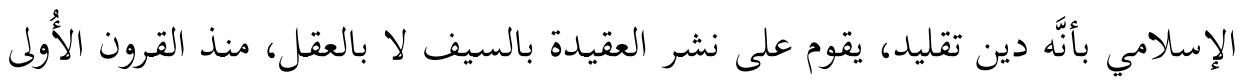
للدولة الإسلامية.

وهنـا نشـير إلى أنَّ الأصل الأول مـن أصـول المعتزلة هـو أصل "التوحيد". وكثيراً مـا

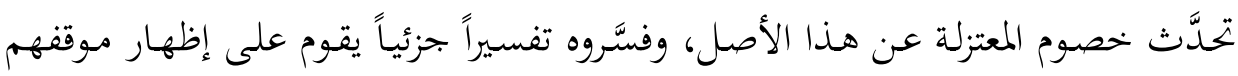

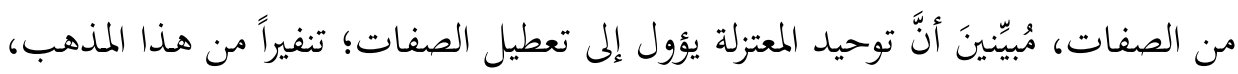

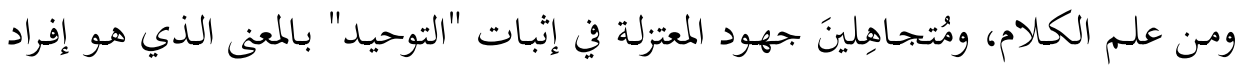

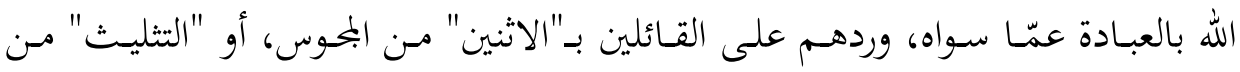

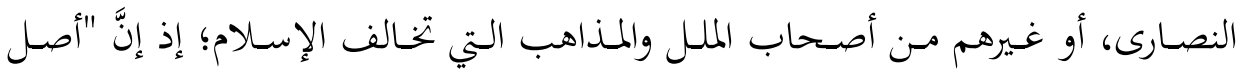

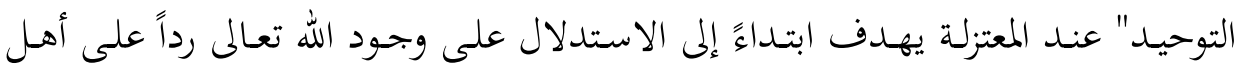

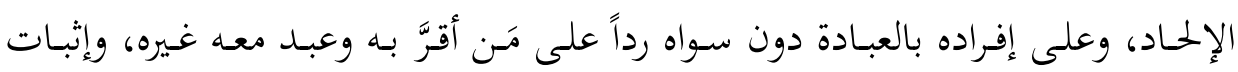

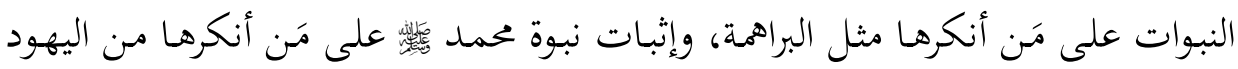
والنصارى.

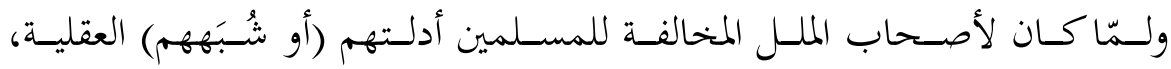
وفلسفاهم الخاصة، بما في ذلك استكناه المسائل العقلية الدقيقة، فقد خاض معهم المعتزلة 


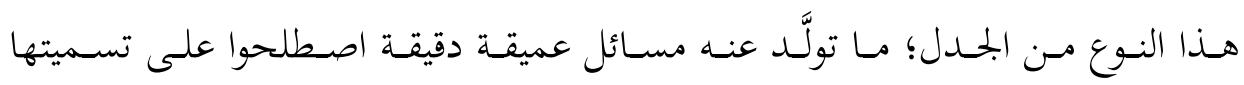

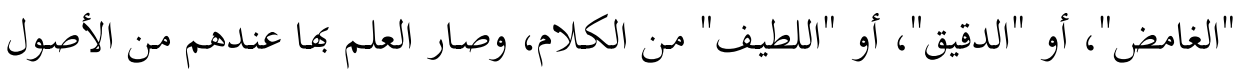

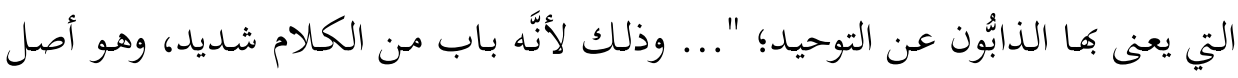

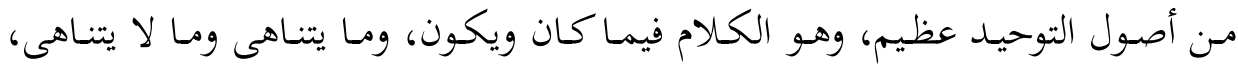

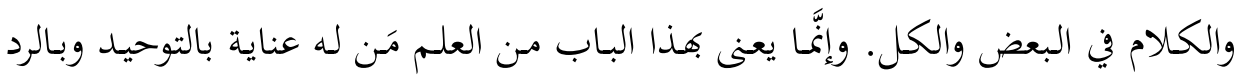
على الملحدين." والخ في البعض و

والذي ينظر في هذه المسائل الدقيقة من غير أنْ يعرف الأسباب المقتضية لها يظن

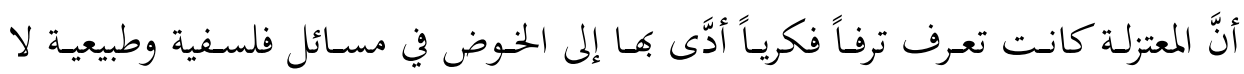

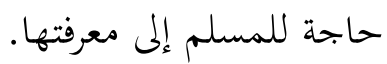

ولكن النظر في هذا السياق الخاص، الذي أخلنا إليه بإيجاز، يُظظهِر أنَّ خوض المعتزلة

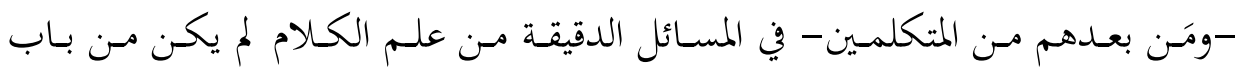

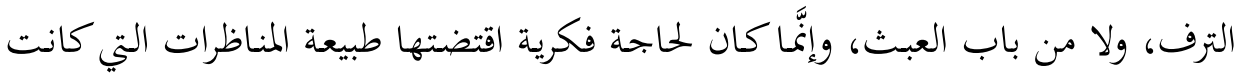

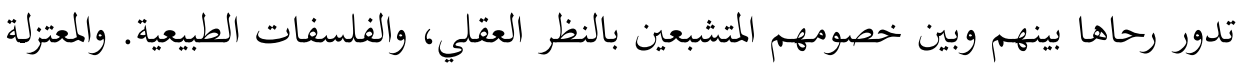

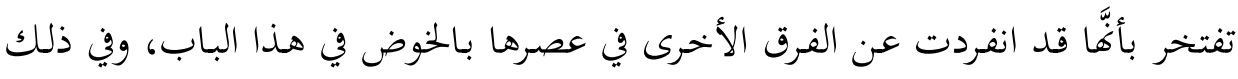

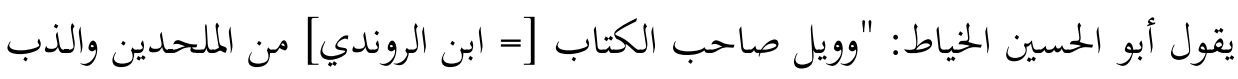

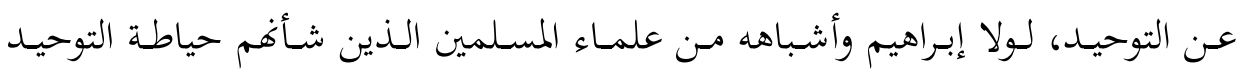

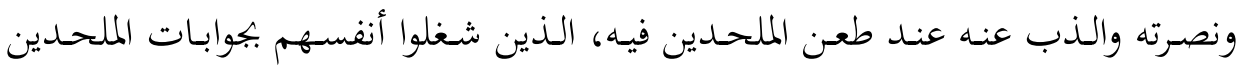

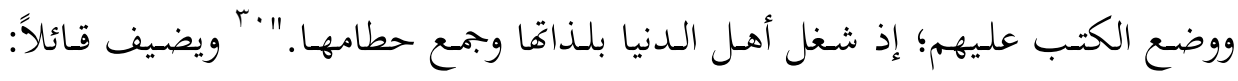

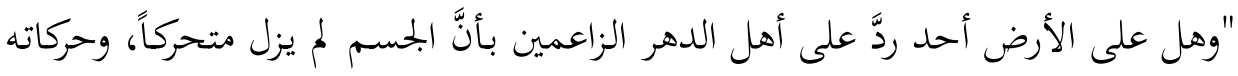

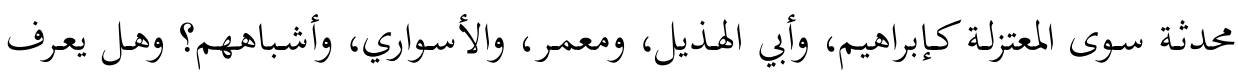

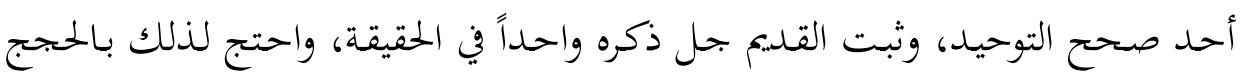

99 ابن الخياط، أبو الحسين. كتاب الانتصار والرد على ابن الروندي الملحد، تحقيق وتقدي: نيبرج، لندن: بيت

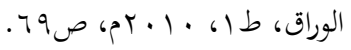

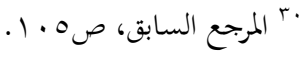


الواضـحة، وألَّنف فيـه الكتـب، وردَّ فيـهـ على أصــاف الملحـــين مـن الدهريـة والثنويـة

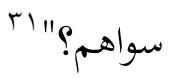

والمقصود أنَّ علم الكلام لم يكن قاصراً على المسائل الخلافية الداخلية، وإنَّا كان

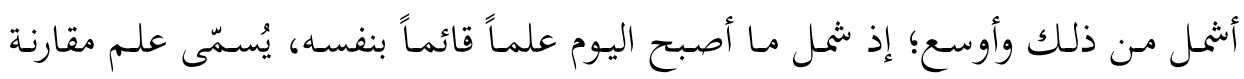

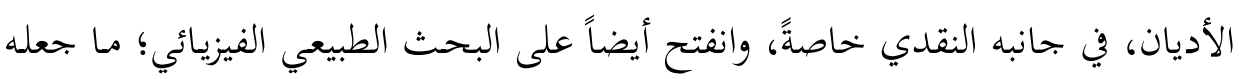

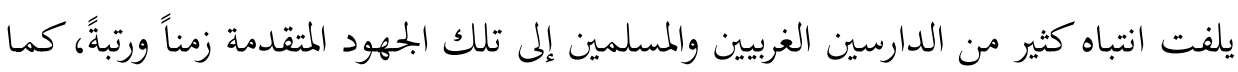

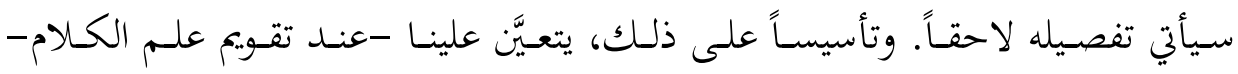
استحضار هذه الجوانب الإيجابية أيضاً، وعدم الاقتصار على ذكر الجوانب التي قد يلحقه

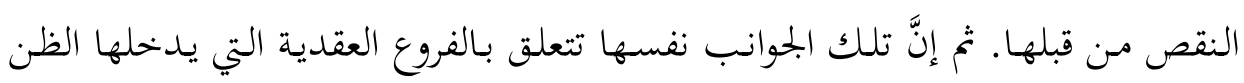
والاجتهاد مثلما ذكرنا آنفاً.

ثالثاً: المستوى الثاني: تحديث النظر الداخلي في علم الكلام بعد الكالام عن تحـديث النظر إلى علم الكـلام، وهو مـا يُعَلُُّ لبنـة أُولى في تحـديث العلم، نعرض بعض ما يتعلق بتحديث النظر داخل علم الكالام، بناءً على التأصيلات التي أسلفناها في النقاط السابقة.

\section{ا ـ التحديث في الطرائق ومناهج إثبات أصول الدين الكبرى:}

ذكرنا سابقاً أنَّ أصول الدين الكبرى (في باب العقائد) هي أصول الإيمان التي تؤول

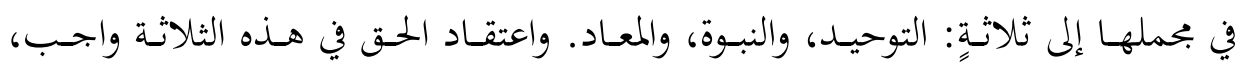

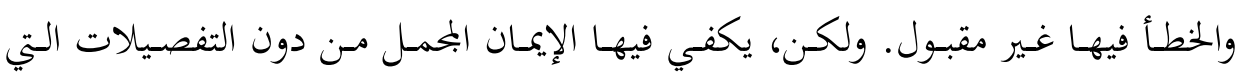

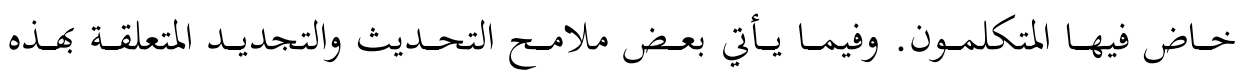

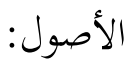


أ. التوحيد: هـ الأصل الأول الذي دعـا إليه القرآن الكريم، مستدلاً على إثباته،

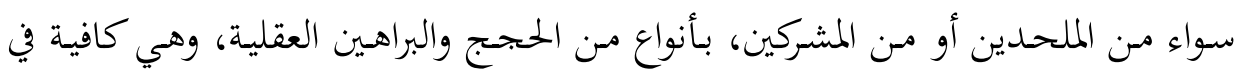

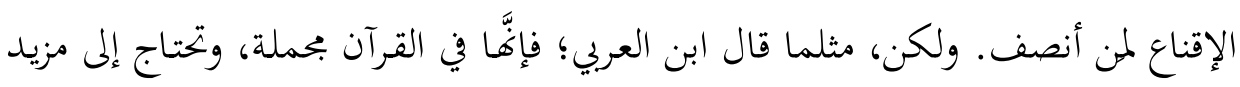

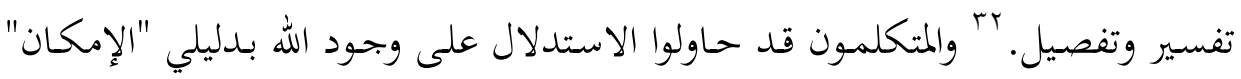

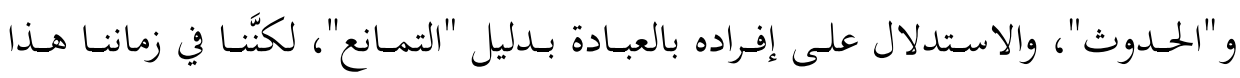

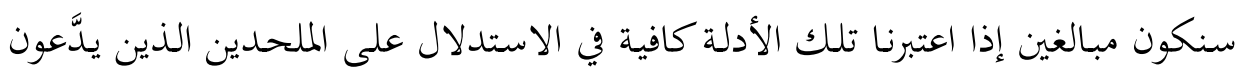
العلمية في إلحادهم، لا من حيث صورة الاستدلال، ولا من حيث مادته، ولا من حيث

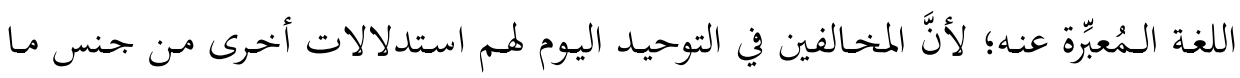

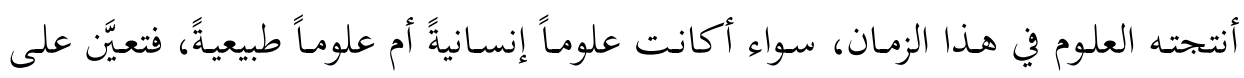
المعتنـين بعلم الكالام الانفتـاح على هذه العلوم، ومنـاهج الاستدلال فيها؛ بغية تكوين مرجع مشترك يُحتخم إليه عند الاختلاف. وقد حصل ذلك في محاولات ثبتت أهميتها، مثلما فعل وحيد الدين خحان في كتابه الذي كتبه عام عـ 9 ام "الإسلام يتحدى"، مُنبّهُاً على أنَّ "المشكلات التي يواجهها الإسلام في هذا العصر، منها ما هو علمي، يوجه إليه

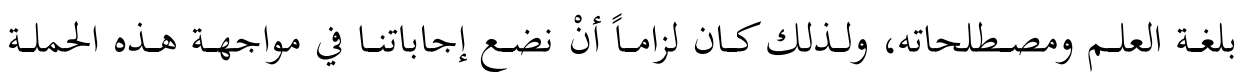

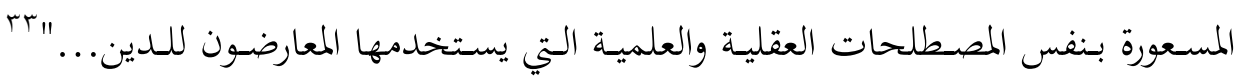
فهـذه -في نظرنـا- مـن بتحليـات تحـديث علـم الكـلام التي ينبغي تكثيرهـا، وتـدعيمها بكتابات أخرى من جنسها. ولا بأس هنا من الاستئناس بكتابات علماء الطبيعة الغربيين

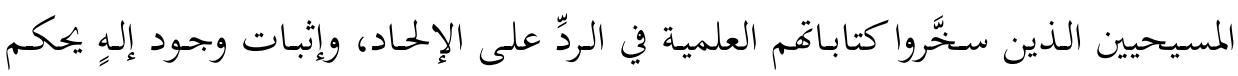

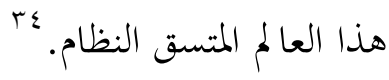

rrr ابن العربي، أبو بكر. قـانون التأويل، دراسة وتحقيق: محمد السليماني، بيروت: دار الغرب الإسلامي، ط؟، .

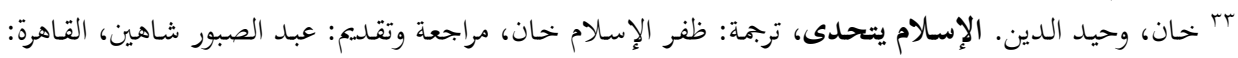

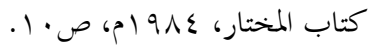

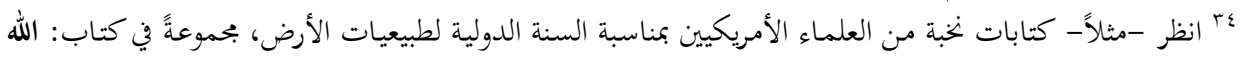
يتجلّى في عصر العلم، وكذا كتاب: العلم يدعو للإيمان، تأليف: أ. كريسي موريسون. 
هـا بالنسبة إلى الملحدين المنكرين التوحيد. أمّا المُعِّرّون بالله تعالى عامةً، وأهل

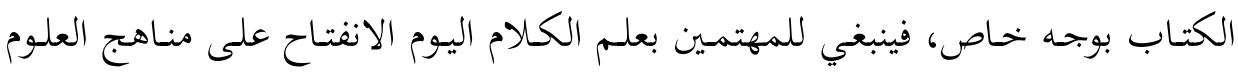

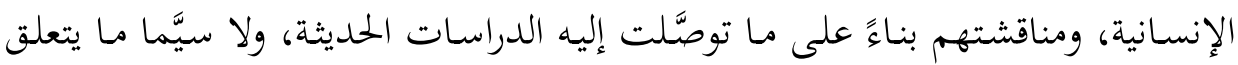
منها بمناهج نقد الكتاب المقدس.

ب. النبوة: حاول المتكلمون الاستدلال على مسألة النبوة بمحورين رئيسين؛ الأول:

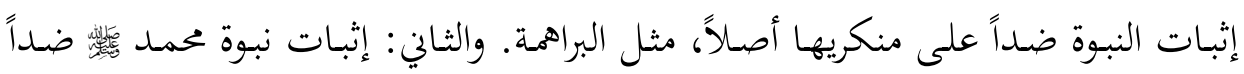

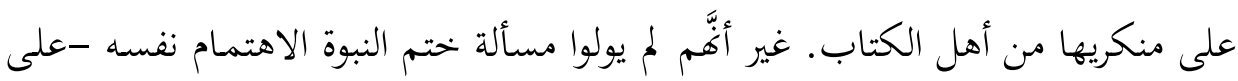

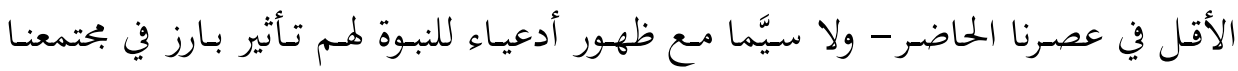

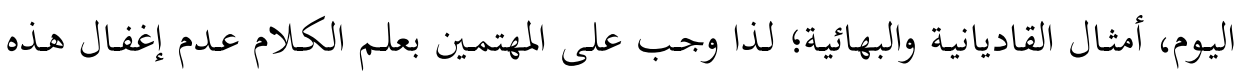

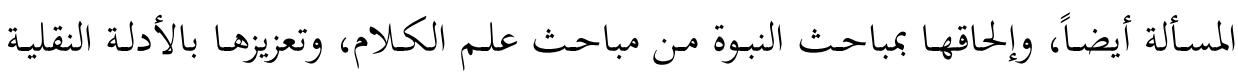
والعقلية.

ت. المعاد: يعد المعاد من الأصول الكبرى التي جاء القرآن ببياها؛ فإن كثيراً من

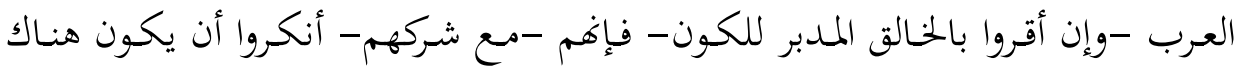

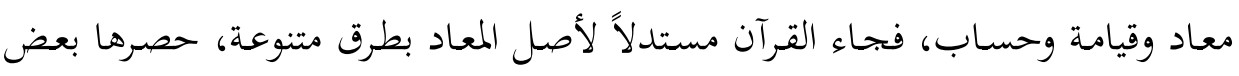

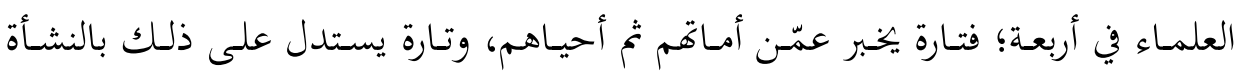

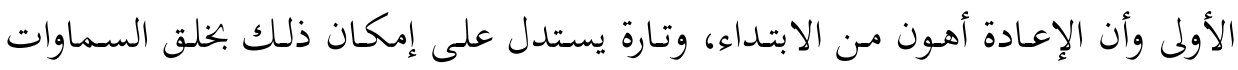

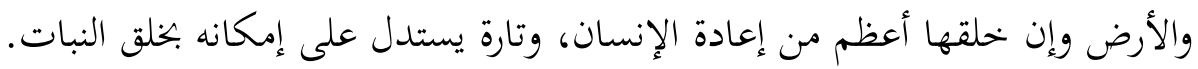
وهذه الطرق القرآنية، وإن كانت نقلية وعقلية في الوقت ذاته، فإن بعض الدارسين

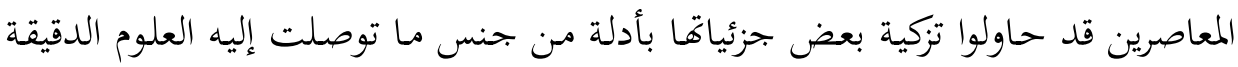

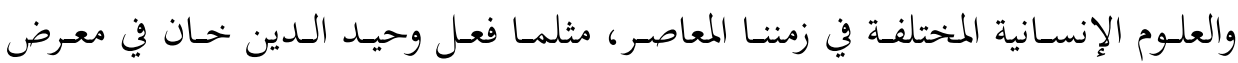
كلامه عن دليل الآخرة من كتابه "الإسلام يتحدى". في ظل ما توصلت إليه العلوم المختلفة في وقتنا الحالي. •r خان، الإسلام يتحدى، مرجع سابق، ص VY وما بعدها. 


\section{Y ب. التحديث المتعلق بفروع الدين العقدية:}

تُعَدُّ هذه المرتبة -مثلما ألمحنا من قبلُ- خلافية بامتياز. و والخلاف فيها دائر بين فرق

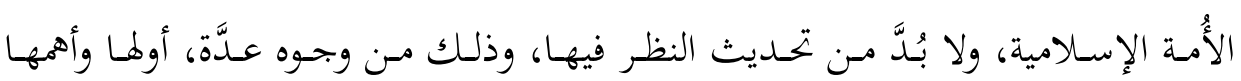

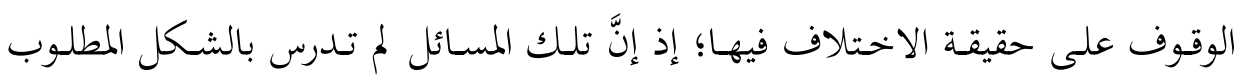

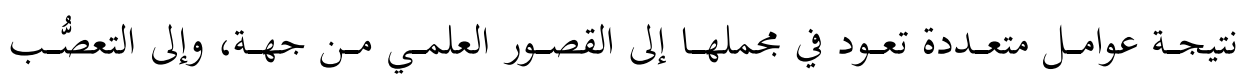

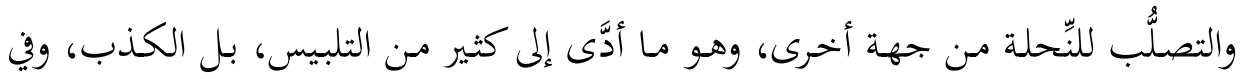

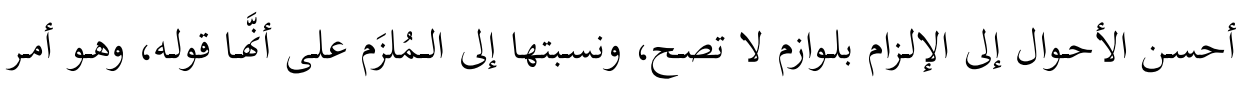

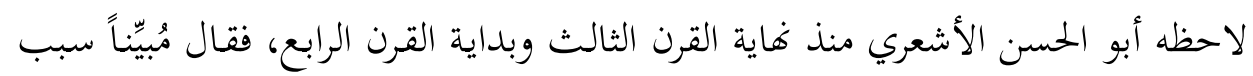

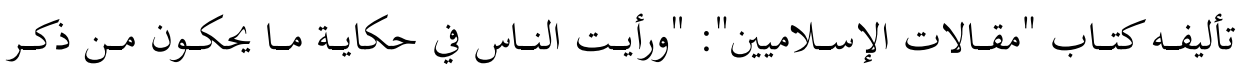
المقالات، ويُصنِّفون في النحل والديانات، من بين مُقصِّر فيما يحكيه، وغالط فيما يذكره

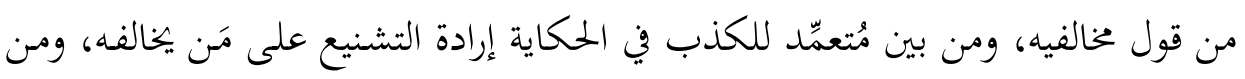
بين تارك للتقصي في روايته لما يرويه من اختلاف المختلفين، ومن بين مَن يضيف إلى قول

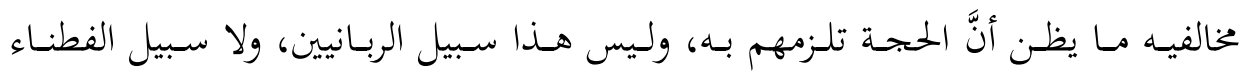

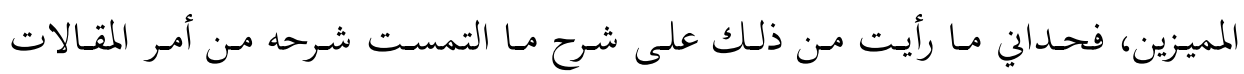
r.". $[\ldots]$

وقـد أشـار إليه البيروين أيضـاً - في أثنـاء انتقـاده منـاهج التـأليف في الفـرق- فقـال: "كنت ألفيت الأستاذ أبا سهل عبد المنعم بن علي بن نوح التفليسي أيَّده الله مُستقبِحاً

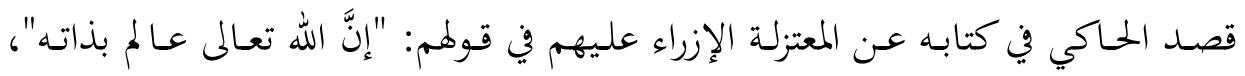

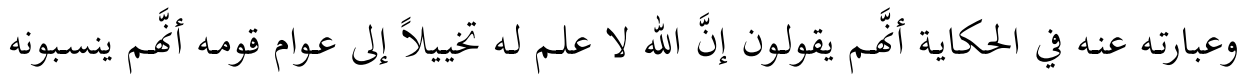

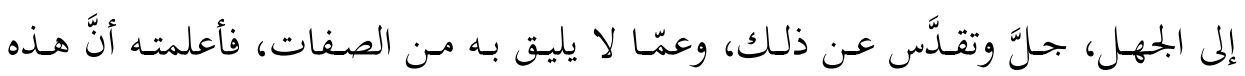

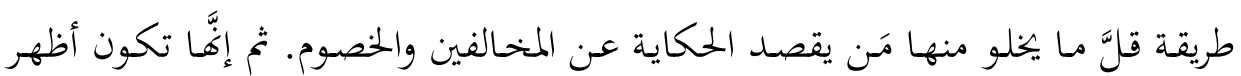

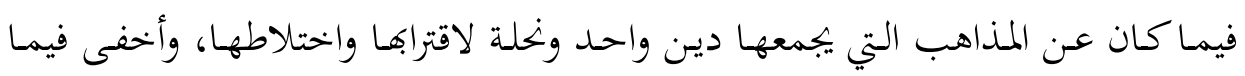

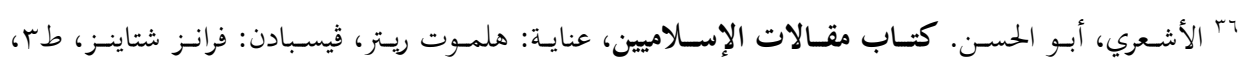

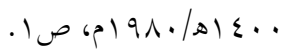


كان عن الملل المفترقة، وخاصة ما لا يتشارك منها في أصل وفرع؛ وذلك لبُعْدها وخففاء

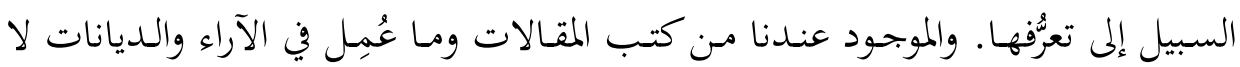
يشتمل إلاّ على مثله.

وما يزال الكثير مـ الباحثين يعتمدون نقل الخصوم عن خصومههم، مـ غير انتباه إلى المزالق العلمية التي قد تنشأ عن ذلك.

وعلى هذا، فإنَّ أُولى خطوات الوقوف على حقيقة الخلاف في هذه المسـائل هي

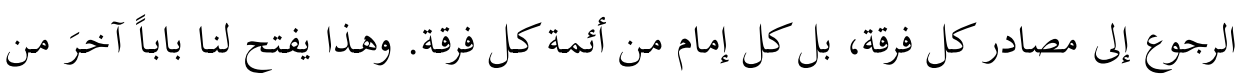

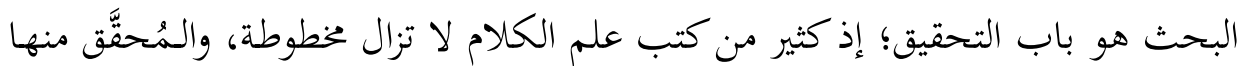
يحتاج إلى إعادة تحقيق وفهرسة وتكشيف؛ تسهيلاً للبحث فيها. بعد ذلك، تأتي خطوة أخرى هي تحليل تلك المسائل، ومقارنتها؛ بغية الوقوف على

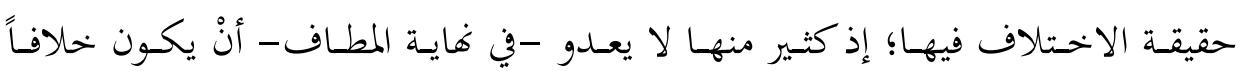

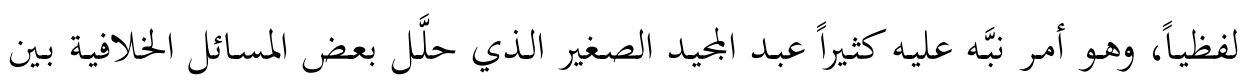

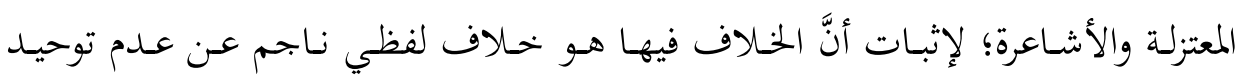

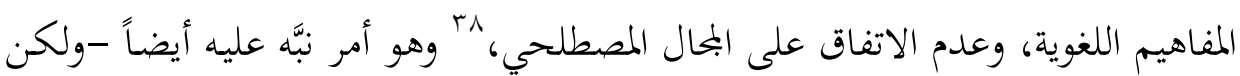

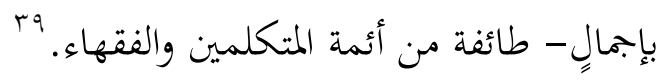
تخم مـاكـان الخـلاف فيه حقيقياً، بـل على فرض أنَّكل الخلافـات في فروع الدين

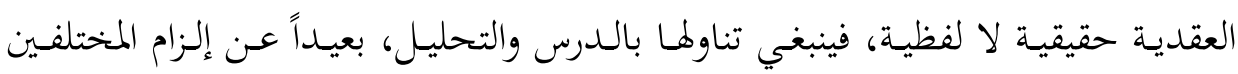

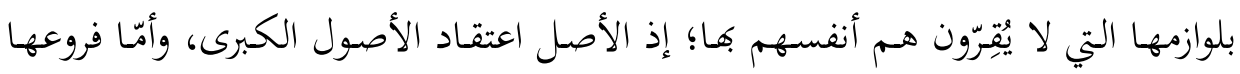

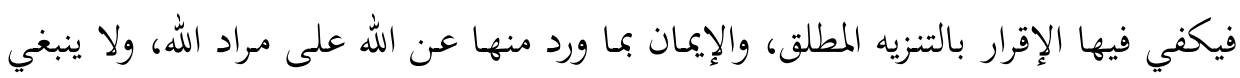

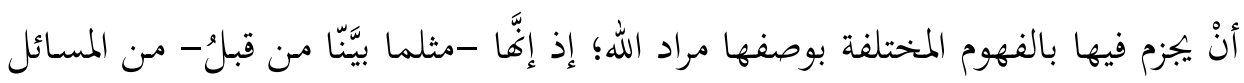

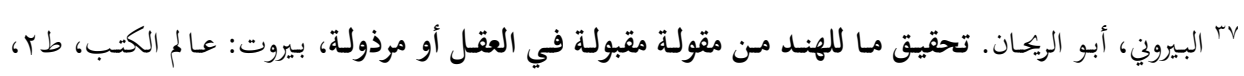

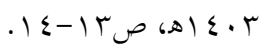

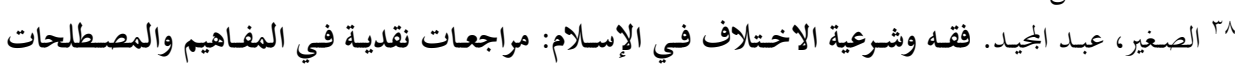

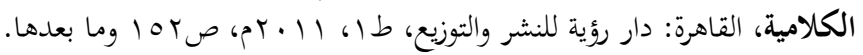

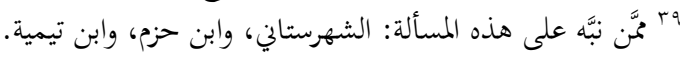




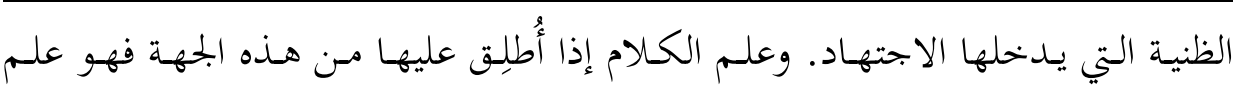
ينتقد، وليس عقيدة تعتقد.

\section{r. تحديث النظر في فروع الكلام الدقيقة:}

يُطلَق "دقيتق الكالام" في الاستعمال الكامي علمى المسـائل التي تُحِوِج إلى التدقيق

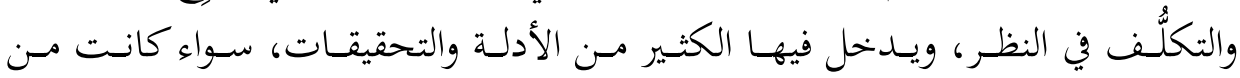

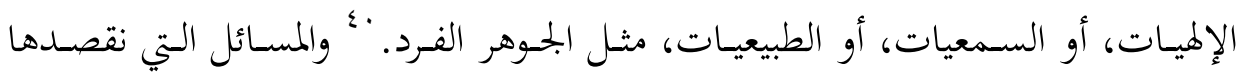

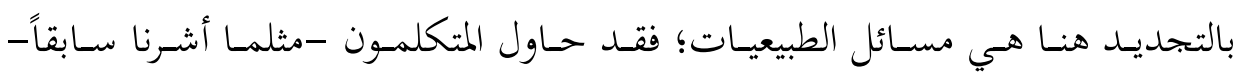

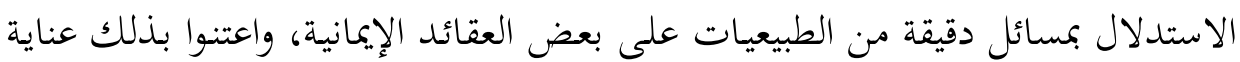

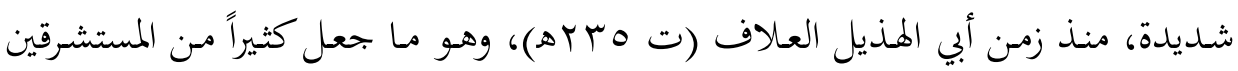

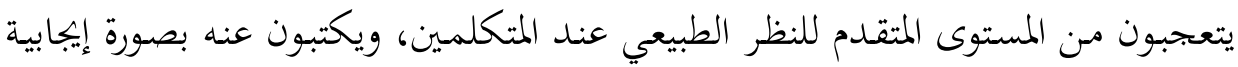

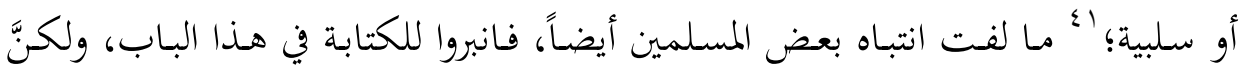

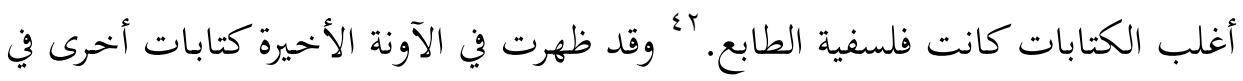

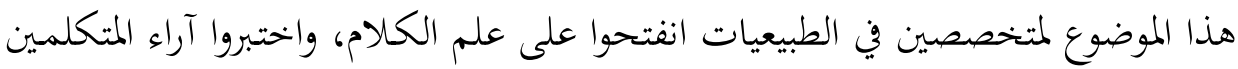

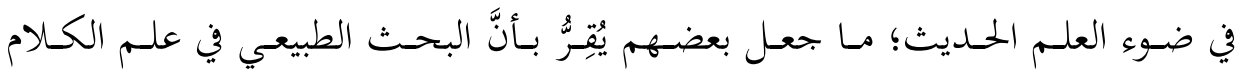

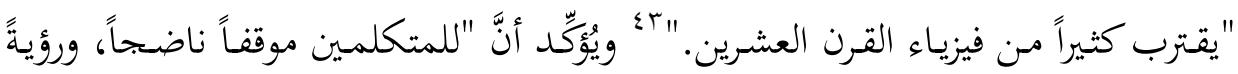

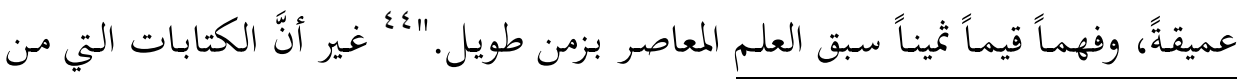

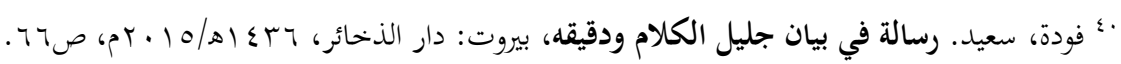
اء انظر مثلاً:

- ولفسون، هـاري. فلسـفة المتكلمسين، ترجمـة: مصطفى لبيـب عبد الغني، القـاهرة: المركز القومي للترجمة،

$$
\text { . } 9
$$

- بينيس، سلومون. مذهب الذرة عندة علد علماء المسلمين وعلاقتهن بمذاهب اليونان والهنود، تحقيق: عبد الهادي

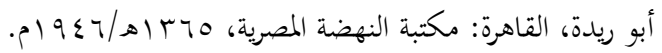
rأ انظر مثلاً:

- بداير عون، فيصل. فكرة الطبيعة في الفلسفة الإسلامية مع بيان مصادرها، القاهرة: مكتبة الحرية الحديثة، .

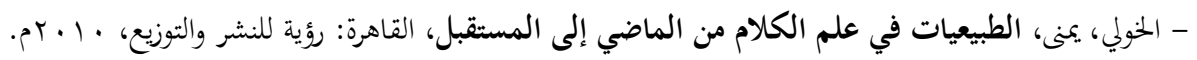

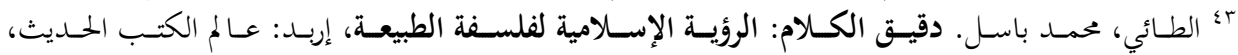




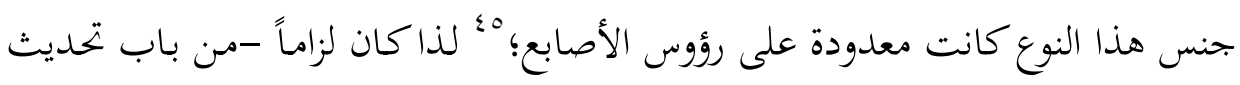

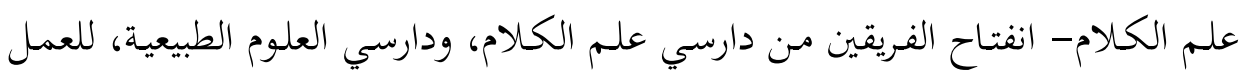
على مستويين:

الأول: جمـع المســائل الكلاميـة المتعلقـة بالطبيعيـات، ودراسـتها مـن منظـور العلـم

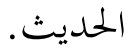

الثاني: جمع شبهات الملحدين المستندة إلى النظر الطبيعي، والردٌّ عليها من جنس المستند الطبيعي، في ظلِّ أصول الدين.

خاتمة:

إذا أردنا أنْ بُحمِل في هذه الخاتمة خلاصة هذا البحث وأهم نتائجه فيمكننا القول: إنَّ المقصود بتحديث علم الكالام ليس إبطال علم الكلام القديم، وإقامة علم آخر جديد محله، وإنَّا تحديثه بالإبقاء على أصله، وتصحيح ما وقع فيه من أخطاء، وإضافة إضماف

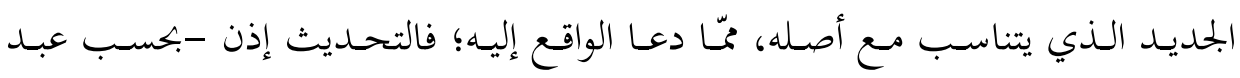

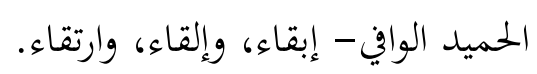

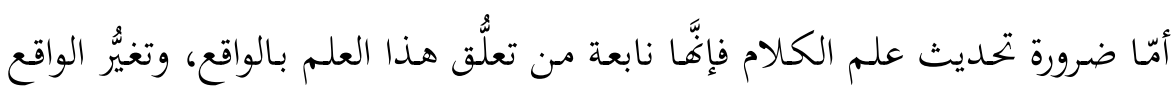

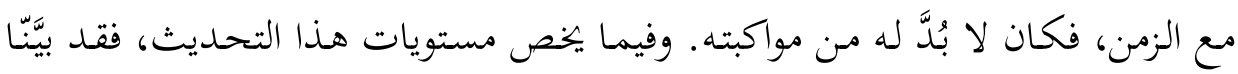

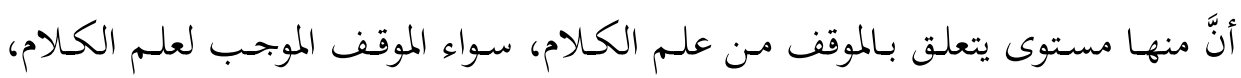

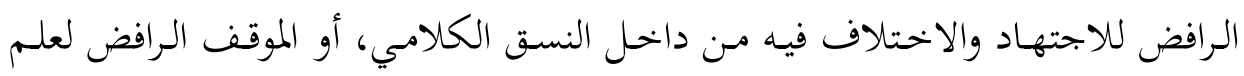
الكهلام جملةً وتفصيلاً.

م؛ انظر مثلاً:

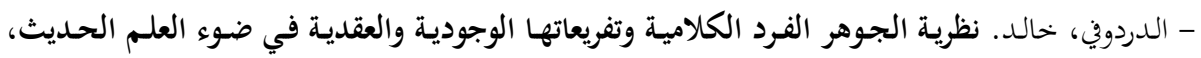

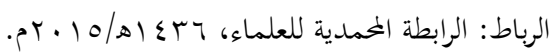

-Alnoor Dhanani, The Physical Theory of Kālam: Atoms, Space, and Void in Basrian Mu'tazili Cosmology. Review by: Josef Van Ess, The University of Chicago Press on behalf of The History of Science Society, Isis, Vol. 87, No. 1 (Mar., 1996). 
وفيما يتعلق بالموقف الأول، فقد حاولنا البحث عن الأسباب التي أدَّت إليه وسبل

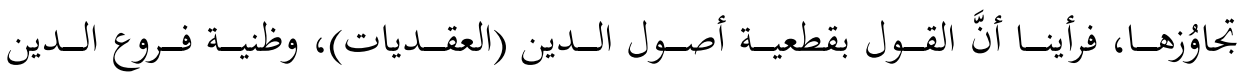

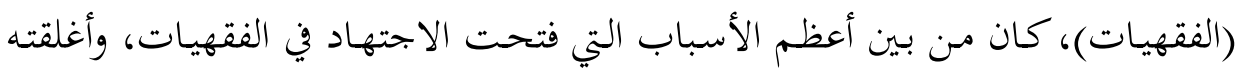
في العقديات، بنـاءً على أنْ لا اجتهاد في قطعي؛ مـا تطلَّب منّا مراجعة مفهوم أصول

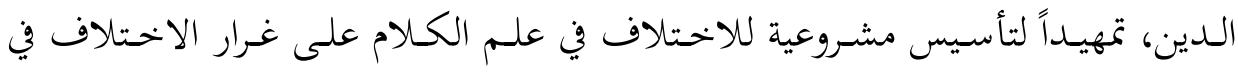

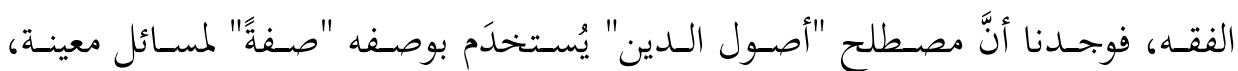

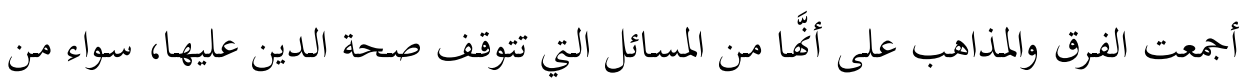

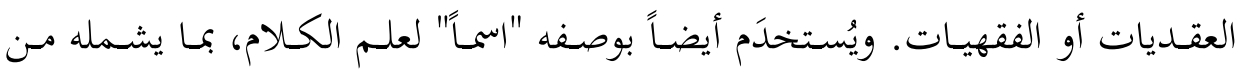

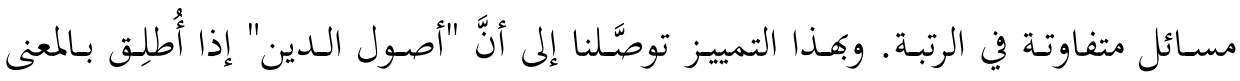

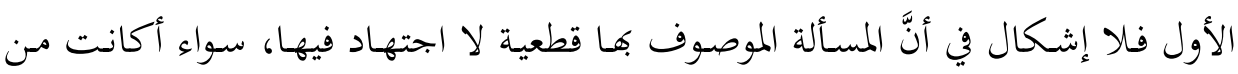

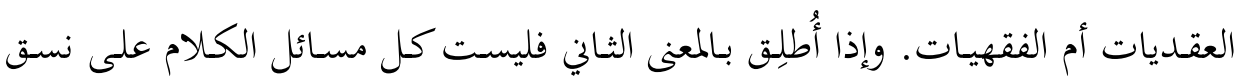
واحدـ؛ إذ منها ما يرقى إلى مرتبةٍ ينال بها صفة أصول الدين، مثل أصل التوحيد والنبوة والمعاد. ومنها مـا يتوسط إلى مرتبةٍة ينـال بهـا صفة فروع الـدين العقديـة، مثل الصفات

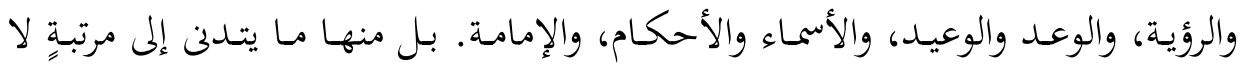

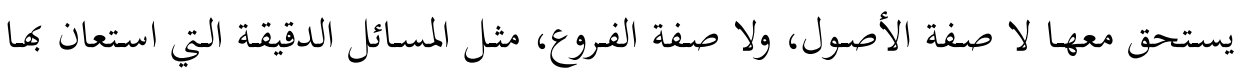

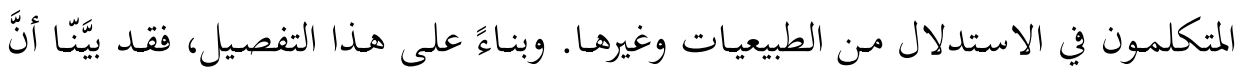

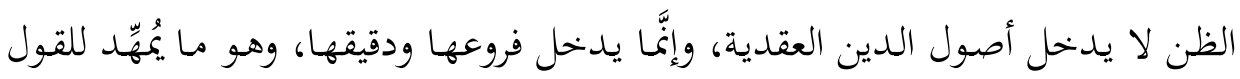
بالاجتهاد العقدي.

وفيما يتعلق بالموقف الثاني، فقد استعرضنا بعض الجوانب التي أغفلها أصحاب هذا الموقف حين تقييمهم علم الكلام، ولا سيَّما جهود المتكلمين في إثبات التوحيد، والردٍّ

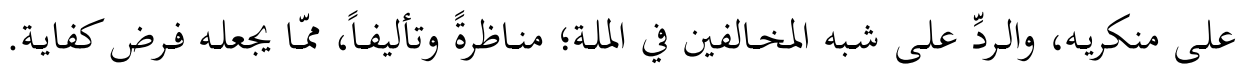

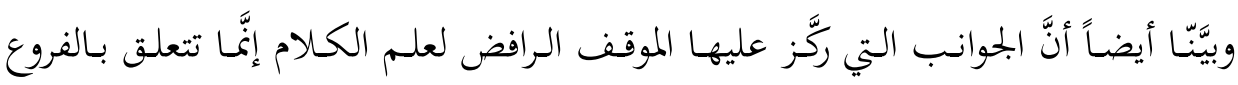

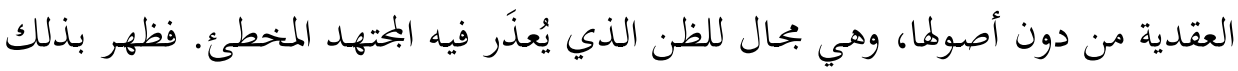

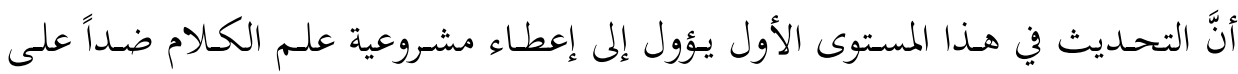


منكريه من جهة، والإقرار بمشروعية الاختلاف داخل النسق الكلامي من جهة أخرى. وهذا كفيل بتجنُّب الفتن الناشئة عن الإقصاء المتبـادل بين فرق الأُمة؛؛ تبديعاً وتضليلاً، بل تكفيراً.

أمّا التحديث في المستوى الثاني فيتعلق بعلم الكلام مـ داخله نفسه. وقد ميَّزنا فيه

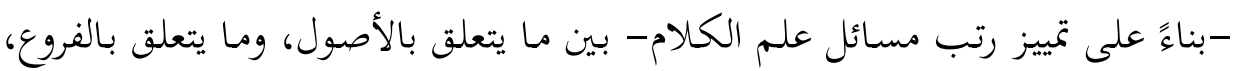
وما يتعلق بالدقيق.

وأمّا بالنسبة إلى الأصول الكبرى (التوحيد، والنبوة، والمعاد) فقد بيَّنّا أنَّ التحديث لا

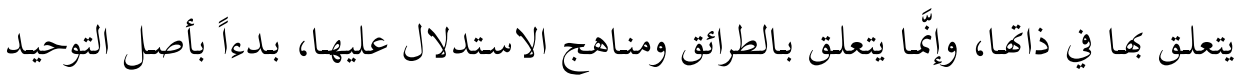

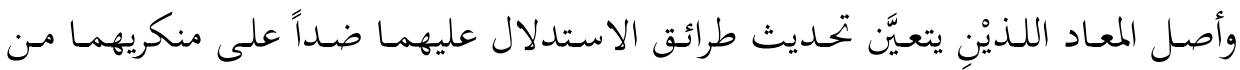
الملاحسدة، بالانفتـاح على العلوم الطبيعيـة التي يستندون إليها في إنكارهما؛ بغيـة توحيد المرجع المشترك عند الاختلاف، والإلزام بالحجة المتفق عليها، إضـافةً إلى الانفتـاح على منـاهج العلوم الإنسانية، ومنـاهج النقـد، في مناقشـة أهل الكتـاب فيما يتعلق بالتوحيد. وأمّا في أصل النبوة فقد بيَّنّا ضرورة تحديث هذا المبحث من علم الكلام، وذلك بإغناء

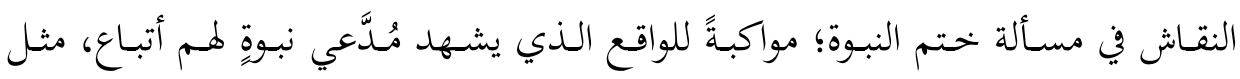
البهائية والقاديانية.

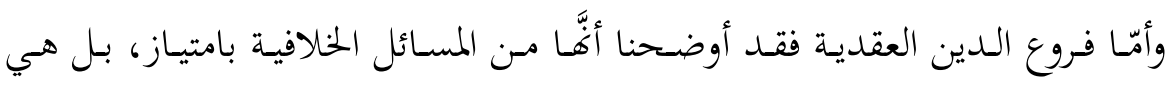
قطب الرحى في الخـلاف الكلامي، وبسـببها وقع الإقصـاء المتبـادل بـين المتكلمـين؛ لذا

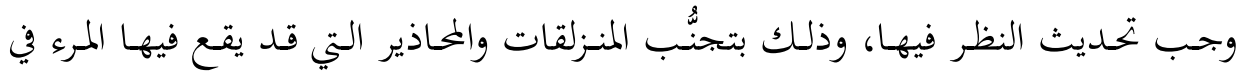

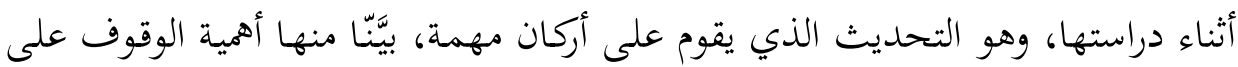

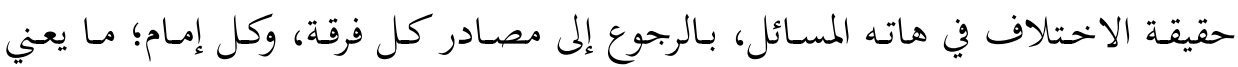
ضرورة الاجتهاد في البحث عن النصوص الكلامية المخطوطة، وتحقيقها، وفهرستها. وأمّا الدقيق من الكلام فيجب تحديثه بجمع النقاشات الكلامية في المسائل الطبيعية، ودراستها في ضوء العلم الحلديث. 


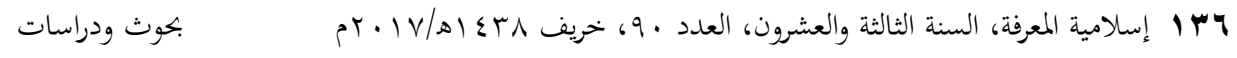

تلك بعض المستويات التي جادت القريحة بالدعوة إلى تحديث النظر فيها في الوقت

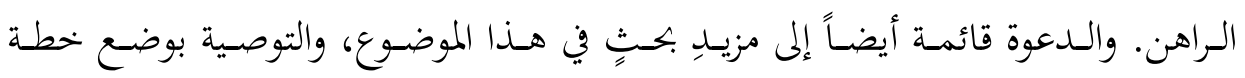
لمشروع يجمع مختلف الرؤى المتكاملة التي تتعلق بتحديث علم الكالام وبتحيده، ثم تنزيلها عملياً بإقامة مؤسسة تنهض بهذا العلم من جديد في ظلِّ قيم الإنصاف والانفتاح بدلاً من الإقصاء والانغلاق. 